\title{
Trade and Productivity in a Transition Economy: the Role of Industry and Export Destination
}

\author{
Carlo Reggiani $^{1} \cdot$ Yevgeniya Shevtsova $^{2}$ (D)
}

Received: 25 August 2017 / Revised: 20 December 2017 /

Accepted: 12 February 2018 / Published online: 26 February 2018

(C) The Author(s) 2018. This article is an open access publication

\begin{abstract}
This paper focuses on the joint role of industry technology intensity and export market characteristics in the analysis of export-related productivity gains. Using a unique database of Ukrainian manufacturing firms in 2000-06, we classify all manufacturing sectors according to their technology intensity and estimate destination-specific learning by exporting effects separately for firms operating in high and low technology sectors. New exporters in high technology sectors enjoy robust long-term productivity growth premia when targeting advanced export markets, consistent with learning through exports. Export entrants in low technology sectors, instead, enjoy mostly short-term productivity improvements regardless of the export destination. Our findings suggest that the systematic distinction between the technology intensity of various industries is a relevant dimension for empirical studies on destination-specific learning by exporting.
\end{abstract}

Keywords Exports - TFP - Destination-specific learning-by-exporting effect · Propensity score matching $\cdot$ Difference-in-differences $\cdot$ Semiparametric estimator

JEL Classification D24 $\cdot$ F14 $\cdot$ L25

\section{Introduction}

Empirical studies on export-productivity links, following the pioneering work by Aw et al. (2000) and Bernard and Jensen (1999), have explored a number of mechanisms that make

Yevgeniya Shevtsova

Y.Shevtsova@liverpool.ac.uk

Carlo Reggiani

carlo.reggiani@manchester.ac.uk

1 School of Social Sciences, University of Manchester, Manchester M13 9PL, UK

2 Management School, University of Liverpool, Liverpool L69 7ZH, UK 
exporters more productive than their non-exporting counterparts. ${ }^{1}$ These mechanisms can be summarized in two main effects.

The first one is a self-selection effect which presumes that, on average, potential exporters have higher productivity prior to entry when compared to firms that remain purely domestic (Clerides et al. 1998; Melitz 2003; Bernard et al. 2003). This hypothesis is supported by substantial factual evidence of differences in characteristics between exporting and non-exporting firms. The second channel that links exports to firm productivity, the so-called learning by exporting effect, suggests that firms that start exporting benefit from further advances in their productivity after entry took place. While the theoretical side of the learning-by-exporting hypothesis has been well understood (Isgut and Fernandes 2007; Eaton et al. 2011; Crino and Epifani 2012), the available empirical evidence is not fully conclusive. This paper contributes to the empirical literature on learning by exporting by jointly exploring two potential channels through which the effect may occur: export market characteristics and industry heterogeneity.

Indeed, the extant empirical evidence reveals higher productivity gains when the target export markets are highly developed, providing access to the latest technologies, product designs, and technical and managerial expertise, that contribute to the superior performance of exporting firms (Wagner 2012). Thus, exporters from developing markets, operating far from the world technological frontier, should have more scope to learn through exports. In fact, in a meta analysis of more than thirty studies, Martins and Yang (2009) find a higher impact of exporting on productivity in developing countries.

At the same time, significant industry heterogeneity of the post-entry productivity gains has been documented by numerous empirical studies. This heterogeneity cannot be solely explained by differences in export market characteristics. In fact, another strand of literature highlights the role of industry characteristics in the learning-by-exporting effect, suggesting that knowledge-absorptive capacities (i.e. firm abilities to internalize new knowledge) can differ among industries (Harris 2005). Hence, firms operating in high technology industries should potentially possess higher absorptive capacities, resulting in higher post-entry productivity benefits for new exporters.

Nevertheless, these sectoral differences have never been thoroughly addressed in conjunction with the choice of the target export market. Hence, this paper adds to the existing literature on learning by exporting by simultaneously estimating the impact of the two main factors that may moderate export-productivity benefits: export destination and industry characteristics. This is particularly important in the light of vast amounts of public funds dedicated to industrial and export-enhancing policies, particularly in developing and transition economies. Given the richness of firm-level datasets, it is now possible to identify the joint effect of these two determinants of export-related productivity improvements. This should allow to target policies toward firms that have the highest potential to contribute to economic growth. In particular, our research aims to refine the answer to the question of which sector(s) should be prioritized as target(s) of industrial policies. For example, given limited resources, is it better to tailor policies toward sectors characterized by a high or low technological intensity and, at the same time, by a high share of firms exporting to more or similarly developed economies?

To answer this question, we use a comprehensive firm-level dataset of Ukrainian manufacturing firms operating in 2000-06. Ukraine is a very relevant case to explore. A former

\footnotetext{
${ }^{1}$ See Greenaway and Kneller (2007), Wagner $(2007,2012)$ and Silva et al. (2012a) for surveys of the literature.
} 
USSR (and then CIS) country, Ukraine is still classified as an emerging market in the IMF World Economic Outlook. The period between 2000 and 2006 is particularly suitable for our analysis as during this time the Ukrainian economy was characterized by stable macroeconomic policies, high dynamism in export markets and a significant reorientation of trade flows toward more advanced Western countries. Furthermore, during the period of study the Ukrainian national legislation was brought into compliance with the WTO rules and regulations in preparation for the WTO accession of 2008. Due to these legislative changes, as well as the recovery from the 1998 Russian financial crisis, the number of Ukrainian firms entering export markets between 2000 and 2006 has increased more than twofold and international trade rose by about $100 \%$. The combination of these two factors creates a fruitful backstage for the analysis of export activity and its impact on firm performance.

From a methodological viewpoint, the analysis is carried in several steps. First, we classify all the industries in our sample into two categories according to their technology intensity (Hatzichronoglou 1997). To account for the role of export market characteristics, we distinguish between firms that: a) enter advanced markets and do not expand to other regions; b) enter markets of similar or lower development levels and do not expand to other regions; c) enter advanced and similar markets at the same time. The choice of global export regions is based on the analysis of the geographical distribution of Ukrainian exports. Second, we address the main methodological challenge when estimating exportrelated productivity gains: the correct identification of the treatment (export entry) effect that can often be blurred by the selection bias. Indeed, the higher productivity growth of export participants can be driven by certain firm-level characteristics that would result in their superior performance even if export entry never took place. This productivity growth is in turn correlated with a firm's decision to enter export markets, giving rise to the selection bias and complicating the identification of the treatment effect. To address this issue this paper uses a matching technique, pairing the export entrants with non-exporting firms with similar pre-export values of productivity and other covariates, including size, average wage and capital intensity (Pisu 2008; Harris and Li 2012; Eliasson et al. 2009). Finally, we use various matching estimators to compare the productivity trajectories of export entrants and their non-exporting counterparts.

The results suggest that the combination of the industry technology intensity and the export market characteristics may explain the industry differences in the post-entry productivity gains highlighted in many studies. In particular, we document that new exporters in high technology sectors that target advanced markets enjoy long-term (up to five years) productivity growth premia. These firms become on average $35 \%$ more productive with respect to their domestic matches in the year of entry and their productivity gap widens to $122 \%$ five years into exporting. Furthermore, new high technology exporters that serve advanced markets grow on average $24 \%$ faster in the year of entry and maintain a positive productivity growth premium up to four years into exporting. At the same time, firms in low technology sectors exhibit no persistent productivity growth premia and show no significant differences across various export markets. For instance, productivity of the new exporters in low technology sectors grows between 19 and $43 \%$ faster in the year of entry. However, these premia become insignificant one to two years into exporting. Thus, our results suggest that productivity gains for new exporters in low technology sectors are more likely to be related to higher capacity utilization rather than export-related productivity improvements.

Overall, our study contributes to the empirical literature exploring the role of export destination characteristics in the post-entry productivity improvements. Due to data limitations, empirical studies added the aspect of export destination to their analysis of the learningby-exporting effect only recently. Most of these studies use micro-level data on highly 
industrialized countries and provide inconclusive evidence in favor of destination-specific learning through exports. Pisu (2008) finds no evidence of destination related learningby-exporting, concluding that productivity advantages in Belgian manufacturing exporters are driven solely by self-selection. Wilhelmsson and Kozlov (2007) - the only study that explores this effect using micro-level data for a CIS country - find no conclusive evidence of learning through exports for Russian manufacturing firms. Several empirical studies based on Slovenian data provide mixed evidence on learning by exporting. Damijan et al. (2004) shows that post-entry productivity improvements occur only in cases when exporting is targeted at advanced foreign markets. De Loecker (2007) - using a cross-section snapshot of firm export destinations - shows that all exporters enjoy additional post-entry productivity gains; however, productivity premia are significantly higher in case of serving advanced markets. Finally, Kostevc (2009) using the same dataset, finds inconclusive evidence of the post-entry learning process, irrespective of target markets. A number of more recent studies on the links between firm productivity and destinations of exports document an increase in export-related productivity premia along the number of export markets served (Andersson et al. 2008 - for Sweden; Wakasugi and Tanaka 2009; Yashiro and Hirano 2009 - for Japan; Castellani et al. 2010 - for Italy; Silva et al. 2013 - for Portugal). Silva et al. (2012b) document stronger learning-by-exporting effects in Portuguese comparative disadvantage sectors and insignificant learning effects when exports are aimed at exclusively non-developed countries, implying that foreign market competition and knowledge spillovers might be the channels through which learning-by-exporting occurs. Furthermore, Silva et al. (2013) document higher productivity gains for: (i) two-way traders; (ii) traders with greater diversification across markets and goods; (iii) trading firms with higher import/export intensity; (iv) exporters that target "difficult" markets. Finally, Damijan and Kostevc (2015) propose a novel sequential mechanism linking firm-level modes of trade and their innovative activity. In particular, the authors argue that firms first improve their innovation potential through imports and only then become exporters, further improving their innovativeness.

In summary, the recent empirical evidence on the exports-productivity nexus implies that learning effects might occur both through the effects of competition and of knowledge spillovers from more advanced export destinations. Learning can be moderated by a number of factors, including export market coverage, types of export markets served, and other firm and industry characteristics (Silva et al. 2012a). However, despite acknowledging industry heterogeneity, most of the studies recalled do not explore in depth the potential significant difference in absorptive capacity among firms in different industries. This paper attempts to fill in this gap in the literature by introducing a new element to the empirical analysis: the technological intensity of the industry where a firm operates. Our findings, indeed, indicate that a systematic distinction between the technological intensity of different industries should improve the results of future studies looking for empirical evidence associated with destination-specific learning through exports.

The rest of the paper is structured as follows. The next section presents the dataset and provides a preliminary analysis of the productivity differences between exporting and nonexporting Ukrainian firms. Section 3 describes the identification strategy and estimation methodology. Section 4 presents the results at the manufacturing level and introduces the analysis of the Ukrainian export structure and technological classification. Section 5 provides the estimates of the post-entry productivity gains taking into account the joint role of industry and export destination. Section 6 presents a set of robustness checks, while Section 7 concludes by briefly discussing the main findings. 
Table 1 Number of firms and share of exporters (\%) by year, 2000-2006

\begin{tabular}{llllll}
\hline Year & 2000 & 2002 & 2003 & 2006 & Average \\
\hline Number of firms & 31,540 & 35,811 & 36,963 & 37,786 & 35,816 \\
Number of exporters & 3,770 & 4,200 & 4,651 & 4,853 & 4,332 \\
Share of exporters & $11.9 \%$ & $11.7 \%$ & $12.6 \%$ & $12.8 \%$ & $12.0 \%$ \\
Number of entrants & - & 881 & 1,123 & 1,002 & 1,005 \\
Number of quitters & - & 953 & 895 & 989 & 897 \\
Entry rate & - & $2.5 \%$ & $3.0 \%$ & $2.7 \%$ & $2.7 \%$ \\
Exit rate & - & $2.7 \%$ & $2.4 \%$ & $2.6 \%$ & $2.5 \%$ \\
\hline
\end{tabular}

\section{Data and Exporting Firms}

\subsection{Descriptive Statistics}

This paper uses the data submitted to the Ukrainian Office of National Statistics (Derzhkomstat) that groups consolidated annual accounts data on the census of manufacturing and service firms operating in Ukraine between 2000 and 2006. ${ }^{2}$ All firms are uniquely defined by their VAT (EDRPOU) number and divided into sectors according to the Ukrainian Office of National Statistics nomenclature, which is comparable to the NACE Rev.1 classification. The data contain information on firm-specific characteristics, such as employment (measured as the annual average number of registered employees), output, sales, tangible and intangible assets, material costs and other types of intermediate expenditure (including $R \& D$ and innovation expenditures), and gross capital investment. The dataset is merged with the Ukrainian Customs office data that contains information on the monetary value of firm-level exports by country and year. All variables were deflated using two-digit subsector price deflators, available from the Ukrainian Office of National Statistics. ${ }^{3}$ We limit the study to firms in the manufacturing sectors (NACE Rev.1 15-36) with at least one employee. The final dataset, used for the statistical analysis, comprises an unbalanced panel with an average of 35,816 firms per year and 237,577 observations covering the period 2000-06, with information showing the entry and exit from export markets. Table 1 shows that the average annual percentage of exporting firms in the sample is around $12 \%$.

Table 2 contains summary statistics for the basic variables - output, capital, employment, and material costs - for selected years. The figures show increasing output and material expenditures alongside a declining average size and capital, caused primarily by the productivity growth and by the increasing number of small and medium market entrants during 2000-06.

The employment figures in Table 2 might cause a concern about the over-representation of large firms in the sample. However, according to the Enterprize Survey data, collected by the World Bank Group, ${ }^{4}$ Ukrainian firms are among the largest in the Eastern European and

\footnotetext{
${ }^{2}$ Access to the data is restricted and not available for public use. The unit of observation is referred to as "firm" in the text. The data have been previously used in Shepotylo and Vakhitov (2015) and Huynh et al. (2016).

${ }^{3}$ Ukrainian State Statistic Committee website: http://www.ukrstat.gov.ua/

${ }^{4}$ http://www.enterprisesurveys.org/.
} 
Table 2 Means (standard deviation) of production function variables $(2000,2003,2005)$
Capital, materials and output are expressed in constant 2000 prices, thousands UAH

\begin{tabular}{llll}
\hline & 2000 & 2003 & 2005 \\
\hline Output & 3340.05 & 5165.02 & 6785.81 \\
& $(58321.74)$ & $(90920.87)$ & $(125440.25)$ \\
Employment & 91.30 & 69.52 & 47.06 \\
& $(645.31)$ & $(640.17)$ & $(334.07)$ \\
Materials & 2188.84 & 3508.90 & 3836.41 \\
& $(40897.19)$ & $(66129.34)$ & $(101161.79)$ \\
Capital & 3776.71 & 2916.31 & 2125.57 \\
& $(35118.78)$ & $(33222.91)$ & $(22152.11)$ \\
\hline
\end{tabular}

Central Asian region in terms of permanent and temporary workforce. The survey reports that Ukrainian firms have the sixth largest permanent workforce in the region. The average firm in Ukraine employs 56.8 permanent workers, while the regional average is 44 workers. In comparison, an average EU-10 firm employs only 37.3 workers. Moreover, firms in manufacturing are more than twice as large as those in retail and other services.

The data cover all Ukrainian manufacturing sectors. ${ }^{5}$ The average number of firms per sector is 5,086. However, as a result of industry specifics and Soviet Union heritage, some sectors, such as Coke \& Chemistry; Rubber \& Plastic and Motor vehicles and trailers are characterized by a smaller number of large firms. Finally, we excluded the Tobacco industry from the analysis as in Ukraine it is traditionally characterized by an oligopolistic structure and, as a result, a very limited number of observations are available.

\subsection{Exporters Characteristics}

This section compares the characteristics of exporting and non-exporting firms in Ukraine. To this end, we follow Bernard and Jensen (1999), De Loecker (2007), inter alia, and calculate the export premia for Ukrainian firms by estimating the following OLS regression with firm-clustered standard errors:

$$
\begin{aligned}
x_{i k t}= & \alpha+\beta E X P_{i k t}+\gamma e_{i k t}+\sum_{j} \delta_{j} Y E A R_{j} \\
& +\sum_{k} \lambda_{k} I N D_{k}+\sum_{j} \sum_{k} \eta_{j k} Y E A R_{j} * I N D_{k}+\varepsilon_{i k t}
\end{aligned}
$$

where $x_{i k t}$ refers to the characteristics of firm $i$ at period $t$ operating in industry group $k$, $E X P$ is a dummy variable indicating the firm's export status, $e_{i k t}$ is the logarithm of the firm's employment. ${ }^{6} Y E A R$ and $I N D$ refer to the time and industry controls, whereas $\varepsilon_{i k t}$ is an i.i.d. error term. The coefficient $\beta$ shows whether the characteristic of an exporting firm is different from the one of its non-exporting rivals, i.e. the firm export premium.

\footnotetext{
${ }^{5}$ Please see Appendix A for the number of firms, the average size (number of registered employees) and the share of exporters by industry.

${ }^{6}$ Note that when employment is the dependent variable, we omit it from the list of the regressors.
} 
In line with previous studies (Bernard and Jensen 1995; Bernard and Wagner 1997; Isgut 2001; De Loecker 2007) the results confirm that export status is positively correlated with firm characteristics such as size, sales, wages, investment, capital intensity and labor productivity.

The results show that exporters pay on average $38 \%$ higher wages; their labor productivity and sales per worker are 1.6 and 2.2 times higher, respectively; they are $77 \%$ more capital intensive and invest $93 \%$ more per worker. Finally, they are on average almost 3 times larger than their non-exporting rivals.

Despite being located in Eastern Europe, Ukraine is not a member of the EU and the longawaited Deep and Comprehensive Free Trade Area Agreement between the EU and Ukraine became operational only in January 2016. Furthermore, Ukraine has become a member of the WTO only in May 2008. Hence, it is likely that during 2000-06 Ukrainian export firms were facing high levels of sunk entry costs, especially when selling to more advanced markets. Indeed, the results in Table 3 show that export premium on labor productivity for Ukrainian exporting firms was at least eight times higher than the productivity premium of Swedish exporters (Andersson et al. 2008, report 14 percent productivity premium for Sweden) and thee times higher than the productivity premium of Slovenian exporters (De Loecker 2007).

Overall, the preliminary findings indicate substantial differences between exporters nonexporters in Ukraine, even after controlling for the size, industry and time fixed effects. This persistent superiority of exporting firms can arise via self-selection or learning by exporting effects and the main task of the following sections is to explore the latter, taking into account both the export market choice and the technological intensity of the industry where a firm operates.

\section{Econometric Strategy}

The causal effect of exports on productivity, that this paper is trying to explore, is often blurred by the simultaneity and by the selection bias.

Table 3 Exporters' premium in Ukrainian firms

\begin{tabular}{lllr}
\hline Firm Characteristic (x) & $\beta$ & $t$-score & $R^{2}$ \\
\hline Average wage (log) & 0.324 & 60.40 & 0.26 \\
Labor productivity $(\log )$ & 0.990 & 111.57 & 0.33 \\
Sales per worker $(\log )$ & 1.187 & 103.68 & 0.27 \\
Capital per worker $(\log )$ & 0.572 & 48.87 & 0.16 \\
Investment per worker $(\log )$ & 0.662 & 40.85 & 0.11 \\
Employment $(\log )$ & 1.366 & 110.23 & 0.24 \\
\hline
\end{tabular}

We have replicated Bernard et al. (2007), De Loecker (2007) and Andersson et al. (2008) using Ukrainian data. All coefficients are significant at $1 \%$ level. All regressions are run using firm-clustered standard errors and control for the size of the firm (except for the employment regression presented in the last row). All regressions include industry and year dummies as well as their interactions. The monetary values are deflated using Ukrainian Office of National Statistics industry deflators. Export premia (i.e. percentage differentials between exporters and non-exporters) are obtained by transforming the estimate of the coefficient $\beta$ using $(\exp (\beta)-1)($ Halvorsen and Palmquist 1980). Adding additional firm controls does not significantly affect magnitude and statistical significance of the results 
The former bias occurs during the estimation of the production function, due to the correlation between the unobservable productivity component and firm input choices. As shown in Olley and Pakes (1996), more capital intensive firms manage to keep operating with lower productivity than their less capital intensive rivals. Hence, the standard estimates of the production function coefficients will result in a downward bias in the capital coefficient and in an upward bias in the labor coefficient. Given the fact that exporters tend to be more capital intensive, this will overestimate the learning by exporting effect. To address this issue, we use a modified version of the Olley-Pakes semiparametric estimator, that proxies unobserved productivity with the observable firm-level variables. ${ }^{7}$

The latter methodological issue in the estimation of export-productivity nexus - selection bias - is related to the fact that exporters may be systematically different from their non-exporting counterparts in certain unobservable intrinsic characteristics, that make them superior to non-exporting firms and are correlated with their export participation decision. Hence, a simple comparison of the average productivity between exporters and non-exporters, presented in Table 3, produces biased estimates of the treatment effect.

In order to obtain consistent estimates of the productivity gains from exporting, any simultaneous relationship between export decision and productivity gains must be removed. To achieve this, the extant empirical studies employ various types of regression-based methods, ${ }^{8}$ as well as matching techniques. ${ }^{9}$ The latter aim to identify a counterfactual that reflects the trajectory of the productivity of an exporting firm, had it not started exporting. Compared to the regression-based methods matching can often avoid the use of functional form assumptions and is also more effective in identifying the availability of comparable untreated observations (non-exporters) for every treated one (an exporter) (Eliasson et al. 2009). However, none of the existing estimators solves the selection problem in every context and the optimal estimation strategy usually depends on the specific selection process and data at hand. Given the relatively short time span and a large number of crosssection observations in the Ukrainian firm-level data we employ a matching methodology to formally evaluate causal effects of exports on productivity.

Assume that $E N T R Y_{i t} \in\{0,1\}$ is an indicator of export entry of the firm $i$ at time $t$, $\omega_{i t+s}^{1}$ is the productivity of this firm at the time $t+s(s \geq 0)$ and $\omega_{i t+s}^{0}$ is the productivity of the same firm had it never started exporting. Then, according to Heckman et al. (1997), the average effect of export entry (treatment) on productivity - the average treatment effect on the treated (ATT) - can be estimated as follows:

$$
\begin{aligned}
E\left\{\omega_{i t+s}^{1}-\omega_{i t+s}^{0} \mid E N T R Y_{i t}=1\right\}= & E\left\{\omega_{i t+s}^{1} \mid E N T R Y_{i t}=1\right\} \\
& -E\left\{\omega_{i t+s}^{0} \mid E N T R Y_{i t}=1\right\}
\end{aligned}
$$

In practice, however, estimating the ATT using Eq. 2 is impossible, as the counterfactual - the productivity of an export entrant if entry did not happen, $E\left\{\omega_{i t+s}^{0} \mid E N T R Y_{i t}=\right.$ $1\}$ - is not observed. The problem can be solved by replacing the unobserved $E\left\{\omega_{i t+s}^{0} \mid E N T R Y_{i t}=1\right\}$ with the observed $E\left\{\omega_{i t+s}^{0} \mid E N T R Y_{i t}=0\right\}$. However, if export entry is non-random, then such a replacement will result in a biased estimate of the ATT

\footnotetext{
${ }^{7}$ The details of the market structure and total factor productivity estimation can be found in Appendices B and $\mathrm{C}$.

${ }^{8}$ See e.g. Damijan et al. (2004), Van Biesebroeck (2005), Wilhelmsson and Kozlov (2007), and Harris and Li (2012).

${ }^{9}$ See e.g. Girma et al. (2004), Eliasson et al. (2009), De Loecker (2007), and Pisu (2008).
} 
with the bias equal to $E\left\{\omega_{i t+s}^{0} \mid E N T R Y_{i t}=1\right\}-E\left\{\omega_{i t+s}^{0} \mid E N T R Y_{i t}=0\right\}$. The matching method precisely addresses this evaluation problem by assuming that all differences between treated and control group can be captured by a vector of observable firm-level characteristics.

\subsection{Identification of Productivity Gains}

The method of matching addresses the problem of missing information in Eq. 2 by assuming that, conditional on a vector of observable firm characteristics in the pre-treatment period $\left(X_{i t-1}\right)$, the unobserved future firm productivity $\left(\omega_{i t+s}^{0}, s \in\{0, \ldots S\}\right)$ is uncorrelated with firm export decision at time $t\left(E N T R Y_{i t}\right)$ :

$$
\omega_{i t+s}^{0} \perp E N T R Y_{i t} \mid X_{i t-1}
$$

If this assumption, often referred to as the conditional independence assumption (CIA), holds, the treatment assignment (export participation) becomes random conditional on $X_{i t-1}$, which allows us using the productivity growth of non-entrants with similar observable pre-export characteristics as a counterfactual outcome (i.e. the productivity growth of export entrants had they never started exporting) (Eliasson et al. 2009). Moreover, Heckman et al. (1998) show that one needs to only assume mean conditional independence in order to obtain unbiased estimates of the ATT:

$$
E\left(\omega_{i t+s}^{0} \mid X_{i t-1}, E N T R Y_{i t}=1\right)=E\left(\omega_{i t+s}^{0} \mid X_{i t-1}, E N T R Y_{i t}=0\right), s \in\{0, \ldots S\}
$$

However, if there are some unobservable firm characteristics that affect the exportparticipation decision as well as firm productivity, the CIA conditions will be violated and some portion of the selection bias will remain. The time-invariant portion of the remaining selection bias can still be removed by adopting a conditional difference-in-differences (DID) matching estimator:

$$
\begin{aligned}
E\left(\omega_{i t+s}^{0}-\omega_{i t-1}^{0} \mid X_{i t-1}, E N T R Y_{i t}=1\right) & =E\left(\omega_{i t+s}^{0}-\omega_{i t-1}^{0} \mid X_{i t-1}, E N T R Y_{i t}=0\right), \\
s & \in\{0, \ldots S\}
\end{aligned}
$$

The DID matching estimator only requires to assume that selection bias is the same in the pre and post-treatment periods, conditional on the vector of the observed firm characteristics in the pre-treatment period. The estimator may still produce biased results due to the remaining time-varying portion of the selection bias. However, as shown by Dehejia and Wahba (1999, 2002) and by Smith and Todd (2005), the DID matching estimator performs the best, as it addresses potential sources of temporally invariant bias as well as discrepancy in the measurement conventions that often bias results in case of cross-sectional matching estimators.

\subsection{Propensity Score Matching}

The dimensionality of the matching problem can be further reduced by applying a propensity score matching technique, that matches treated and non-treated firms based on their conditional probability of entering exporting. As shown in Rosenbaum and Rubin (1983), firms with the same value of the propensity score will have the same distribution of the observable pre-treatment firm characteristics. Hence, matching on the propensity score will balance the distribution of covariates in the treated and control group. 
We estimate the probability of starting to export (propensity score) using a probit model with a binary dependent variable, ENTRY $Y_{i t}$, on a set of lagged independent variables:

$$
\operatorname{Pr}\left\{E N T R Y_{i t}=1\right\}=\Phi\left\{X_{i t-1}, \ldots\right\},
$$

where $\Phi$ is a normal cumulative distribution function, $X_{i t-1}$ is a set of observable firm-level characteristics affecting both productivity and the probability of export entry (all in logs). The choice of firm characteristics in $X_{i t-1}$ is based on the existing literature and it includes lagged values of the estimated total factor productivity (henceforth, TFP), the number of employees, the average wage, the capital per worker, and the 4-digit industry dummies to control for the aggregate demand and supply shocks.

The identifying assumption to estimate the learning by exporting effect is that any unobservable firm characteristic left in the estimated propensity scores is not correlated with its export decision. In order to relax this assumption we tried adding additional firm characteristics (e.g. location, possession of intangible assets). However, this has produced no significant changes in the results.

The matching is performed using the nearest neighbor matching method in the period when the firms first enters export market. ${ }^{10}$ As shown by Heckman et al. (1997) two main sources of bias in empirical studies arise when treated and controls: 1) operate in a different economic environment (market); 2) have different distributions of observable variables. To address the first bias we match the firms for each 2-digit NACE industry and year separately. The second bias, instead, is tackled by matching over the region of common support. As a result, we obtain a sample of exporting and matched non-exporting firms, required to estimate the causal effect of export on productivity.

\subsection{Matching Estimators}

Having obtained a counterfactual, we compare the productivity levels and growth rates of export entrants and their non-exporting matches, using both a cross-sectional (henceforth, CS) and DID version of the matching estimator. Both are weighting estimators: they take an average of the untreated matched observations to construct an estimate of an unobserved counterfactual for every treated observation. ${ }^{11}$

The CS matching estimator given by Eq. 7 calculates the ATT as an average difference between the productivity of export entrants and the weighted average productivity of a control group for every post-entry period. Equation 7 assumes that $N$ firms start exporting in period $t$, and $C(i)$ is a set of controls matched to each export entrant $i$. The number of control firms in each matched set is denoted by $N_{i}^{c} \cdot \omega^{1}$ and $\omega^{c}$ are the estimated productivity of treated firms and their matches. $\psi_{i j}$ is the weight of the $j^{\text {th }}$ observation in constructing the counterfactual for the $i^{t h}$ treated observation: $\psi_{i j}=\frac{1}{N_{i}^{c}}$ if $j \in C(i)$ and zero otherwise. In other words, every firm that enters exporting is matched with $N$ control firms that never export and have propensity scores $p_{i}$ closest to the one of the export entrant.

$$
\beta_{t+s}^{P S M-C S}=\frac{1}{N_{t+s}} \sum_{i}\left(\omega_{i t+s}^{1}-\sum_{j \in C(i)} \psi_{i j} \omega_{i t+s}^{c}\right), s \in\{0, \ldots S\}
$$

\footnotetext{
${ }^{10}$ The matching procedure was performed with the help of the STATA teffects psmatch command.

${ }^{11}$ This paper matches every exporting firm with the three closest nearest neighbors in terms of its propensity score.
} 
At the same time, the DID matching estimator, presented in Eq. 8, estimates the ATT by comparing the difference between the pre and post-entry productivity of the export entrants with the difference between the pre and post-entry productivity of their matched controls.

$$
\beta_{t+s}^{P S M-D I D}=\frac{1}{N_{t+s}} \sum_{i}\left(\left(\omega_{i t+s}^{1}-\omega_{i t-1}^{1}\right)-\sum_{j \in C(i)} \psi_{i j}\left(\omega_{i t+s}^{c}-\omega_{i t-1}^{c}\right)\right), s \in\{0, \ldots S\}
$$

In other words, the CS matching estimator assumes that conditioning on the pre-export observable firm characteristics resolves the problem of selection bias in the post-entry period. On the other hand, the DID matching estimator assumes that selection bias, that may remain in the matched sample, is time-invariant and can be removed by comparing pre and post-treatment differences of export entrants and their matches.

\section{Export Entry and Productivity Gains}

\subsection{Results at the Manufacturing Level}

We start by presenting the estimates of export productivity premia based on the CS and DID matching estimators at the aggregate level, i.e. for all firms in the sample.

Table 3 summarizes the ATT at the manufacturing level. Columns (a) and (b) present the estimates based on the cross-sectional matching estimator presented in Eq. 7. In particular, column (a) shows the differences in TFP levels between export entrants and matched nonentrants for every period; column (b), instead, shows the differences in year-on-year TFP growth rates between export entrants and matched non-entrants at every period. Column (c) uses the $D I D$ version of the matching estimator given by Eq. 8 and shows the difference in the productivity growth rates between export entrants and matched non-entrants, with

Table 4 The learning by exporting effect: CS and DID estimators

\begin{tabular}{llllll}
\hline Export premia at time & (a) & (b) & (c) & Treated & Controls \\
\hline $\mathrm{t}-1$ & -0.017 & -0.010 & & 938 & 1,951 \\
$\mathrm{t}$ & $0.245^{* * *}$ & $0.227 * * *$ & $0.227 * * *$ & 938 & 1,949 \\
$\mathrm{t}+1$ & $0.311^{* * *}$ & $0.102 * * *$ & $0.302 * * *$ & 909 & 1,794 \\
$\mathrm{t}+2$ & $0.377 * * *$ & $0.065 * * *$ & $0.383 * * *$ & 904 & 1,665 \\
$\mathrm{t}+3$ & $0.331 * * *$ & $0.028 * * *$ & $0.309 * * *$ & 737 & 1,422 \\
$\mathrm{t}+4$ & $0.270^{* * *}$ & -0.014 & $0.288^{* * *}$ & 537 & 1,044 \\
\hline
\end{tabular}

The balancing indicators confirm that matching has been fairly successful in balancing the differences in the covariates between the treatment and the control group. The mean standardized bias over the covariates used in the propensity score estimation declines from 56 percent before the matching to 3 percent after the matching. Pseudo $R^{2}$ - another balancing indicator - reduces from 0.24 to almost zero. The low value of the pseudo $R^{2}$ confirms that no statistically significant differences in the pre-export observable firm characteristics remain between export entrants and their matches

The estimated parameters are based on the cross-sectional (columns a and b) and difference-in-differences (column c) propensity score matching estimators with a weighting regime that matches every export entrant to three non-exporters with closest estimated probability to enter export markets (propensity scores). The number of treated and controls decreases as we estimate future productivity effects. The matching is performed at the time of export entry $t$. $* * *$ - significant at $1 \%$ level; **- significant at $5 \%$ level; *-significant at $10 \%$ level 
Table 5 Industry specific results: summary

Evidence on learning by exporting

\begin{tabular}{lll}
\hline Short-term effect & Long-term effect & No effect \\
\hline Coke \& chemical products & Food \& beverages & Printing \& publishing \\
Rubber \& plastic & Textile, leather, apparel & \\
Non-metallic minerals & Wood \& paper & \\
High-tech machinery & Metallurgy \& basic metals & \\
& Machinery \& equipment \\
& Motor vehicles, trailers \\
& Furniture/Manufacturing n.e.c. \\
\hline
\end{tabular}

Detailed estimates for each sector can be found in Appendix D

respect to their pre-export $(t-1)$ levels of productivity. The magnitude of the coefficients can be interpreted as percentages.

Overall, the results, presented in Table 4, are in line with the previous empirical studies on the export-productivity nexus: the productivity gap of Ukrainian exporters in the year of entry is $24.5 \%$, which is higher compared to Slovenian manufacturing firms $(8.8 \%$, DeLoecker 2007), but is similar to the one of the small Swedish exporters (22.5\%, Eliasson et al. 2009). However, differently from the previous literature, our findings reveal a widening productivity gap within the first four years of entry: the gap rises to $33 \%$ in the fourth year of entry and, overall, remains significant during the first five years of export.

Next we look at the exports premia in terms of year-on-year productivity growth rates $\left(\omega_{t+s}-\omega_{t+s-1}\right)$ and in terms of productivity growth with respect to pre-export productivity levels, $\left(\omega_{t+s}-\omega_{t-1}\right)$. As shown in column (b) new exporters grow faster with respect to matched non-exporters in the first four years of entry: their year-to-year productivity growth premium is $22.7 \%$ at $t$ and remains positive and significant until $t+3$, becoming smaller over time. Furthermore, the results of the DID matching estimator, in column (c), reveal that exporters grow progressively faster than their non-exporting counterparts with respect to their pre-export levels of productivity. The difference in these productivity growth rates between exporters and matched non-exporters increases from $22.7 \%$ at $t$ to $31 \%$ at $t+3 .{ }^{12}$ This persistent productivity growth premium explains the widening gap in the productivity levels between new exporters and their non-exporting matches, presented in column (a). This evidence is consistent with continuous learning through exports. Furthermore, the pre-export $(t-1)$ productivity differentials are insignificant and close to zero, which provides additional support to the validity of the matching methodology. Finally, the exporters premium in terms of productivity levels at time $t$ is similar to the premium in terms of productivity growth at the time $t(24.5 \%$ versus $22.7 \%)$, suggesting that productivity gains in the year of entry are related to the start of exporting activity.

It should also be noted that during the period of study Ukraine was still characterized as a transition economy. Hence, it is not surprising that we find evidence consistent with learning through exports. Similar to the Slovenian economy, explored in De Loecker (2007), Ukraine has undergone structural transformations and a reorientation of trade toward more

\footnotetext{
${ }^{12}$ As discussed in Section 4.1, the use of the DID matching estimator significantly improves the quality of evaluation in the studies based on the non-experimental data (Smith and Todd 2005; Blundell and Costa Dias 2000).
} 
Table 6 Classification of manufacturing industries based on technology

\begin{tabular}{ll}
\hline Low-technology industries & High-technology industries \\
\hline Wood \& paper & Food \& beverages \\
Coke \& chemical products & Textile, leather, apparel \\
Non-metallic minerals & Printing \& publishing \\
Metallurgy \& basic metals & Machinery \& equipment \\
Furniture/Manufacturing n.e.c. & High-tech machinery \\
Rubber \& plastic & Motor vehicles, trailers \\
\hline
\end{tabular}

Details of the procedure can be found in Appendix E

advanced Western markets, that offered more scope for productivity improvement. Finally, Ukraine is still ranked lower than Slovenia in terms of economic development, which may explain the higher estimates of the export-productivity premia for Ukrainian export entrants.

The summary of the results at two-digit manufacturing industry level is presented in Table $5 .{ }^{13}$ The findings reveal significant industry heterogeneity in export-productivity premia among Ukrainian export entrants. In most cases, we find that engaging in export activity has an immediate positive effect on productivity growth. However, such a short-term effect can indicate either an increased capacity utilization or economies of scale that arise due to the larger size of international markets (Kostevc 2005). The results for the productivity growth premia in later years, more consistent with the evidence of learning through exports, vary significantly. Whereas some industries keep the growth premia during the whole trajectory of exporting, others only enjoy a short-term productivity boost.

The industry heterogeneity of the learning-by-exporting effect is in line the previous empirical studies and it can be related to a number of aspects that can potentially affect its magnitude and significance. ${ }^{14}$ Firm's knowledge-absorptive capacities (i.e. firm abilities to internalize new knowledge) is one of the factors affecting export-related productivity gains (Harris 2005).

Indeed, the producers of high-tech products, with significant amount of intangible assets and R\&D expenditure, might enjoy higher productivity premia. This effect arises mainly due to the larger scope for technology improvement as well as the need to remain competitive in high-tech foreign markets. On the other hand, low-tech exporters from developing countries might compete successfully solely on the basis of the low cost of production. At the same time, a number of empirical studies have also shown that productivity gains may depend on export destination, as summarized by Wagner (2012). Indeed, one can argue that the scope for learning, resulting in higher productivity gains, is higher when the firm targets more advanced markets due to more learning opportunities related to such exports. To disentangle the heterogeneity in the industry-specific productivity gains and provide more insights into the nature of the learning by exporting effect, the following sections will explore the joint role of industry and export destination in more details.

\footnotetext{
${ }^{13}$ The complete set of results can be found in Appendix D.

${ }^{14}$ For a survey of the recent literature on learning-by-exporting see Silva et al. (2012a) and a meta-study by Martins and Yang (2009).
} 


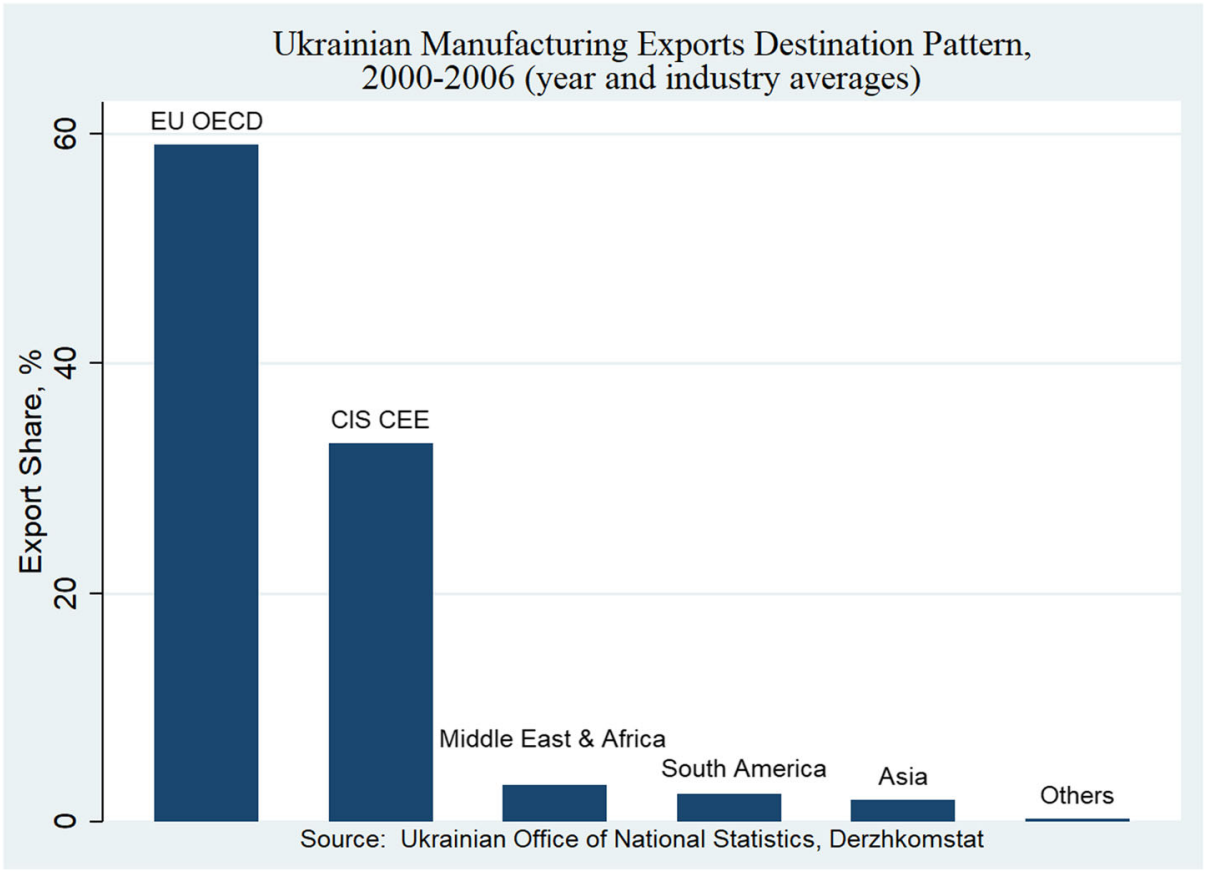

Fig. 1 Ukrainian manufacturing Exports Destination Pattern, 2000-2006 (year and industry averages)

\subsection{Industry Technological Intensity, Export Destination and Productivity Gains}

To analyze the moderating effect of knowledge-absorptive capacities on export-related productivity gains, we apply the Hatzichronoglou (1997) methodology, using the parameters of our data to obtain the classification of the technological intensity of the Ukrainian manufacturing sectors. ${ }^{15}$ The results, presented in Table 6 , reveal that the majority of the high-technology sectors correspond to the ones that experience long-term productivity gains (Table 5).

Another potential channel through which learning by exporting occurs can be captured by adding information on firm-level export orientation. To explore this aspect we first present the structure of Ukrainian exports. The main export destinations include European Union and OECD countries (henceforth, EU-OECD), Central and Eastern Europe (henceforth, CEE) countries, Commonwealth of Independent States (henceforth, CIS), Middle East and Africa, South America, Asia and Others.

As seen in Fig. 1, around 60\% of Ukrainian exports between 2000 and 2006 targeted the EU and other OECD countries, while around $30 \%$ were destined to the countries of the Commonwealth of Independent States. ${ }^{16}$ Together, these two regions account for almost

\footnotetext{
${ }^{15}$ The Hatzichronoglou (1997) method was used to construct the OECD technological industry classification. The full list of NACE Rev.1 industries corresponding to the OECD technology classification can be found at: https://www.oecd.org/sti/ind/48350231.pdf.

${ }^{16}$ We include the New EU Member States in the Central and Eastern Europe Category to account for the economic and political similarities with the other countries of the Soviet Block and to account for the fact that they joined the EU only in/after 2004.
} 
Table 7 Export orientation profile of Ukrainian exporters

\begin{tabular}{lllll}
\hline & EU-OECD & CIS & CEE & Others \\
\hline EU-OECD & $28 \%$ & $13 \%$ & $4 \%$ & $2 \%$ \\
CIS & & $28 \%$ & $4 \%$ & $1 \%$ \\
CEE & & & $3 \%$ & 0 \\
Others & & & $1 \%$ \\
\hline
\end{tabular}

90\% of Ukraine's export flows in monetary terms. The summary of the firm export orientation profile, presented in Table 7, confirms that EU-OECD, CIS and CEE markets were the most popular destinations among Ukrainian exporters. On average, over $90 \%$ of Ukrainian exporters target those markets. The destinations pattern is relatively stable across industries, which further confirms that the variation in productivity gains cannot be explained solely by the destinations of exports. Finally, the export orientation portfolio, presented in Table 7 , confirms that around $40 \%$ of exporters tend to target more than one export region.

Taking into account the geographical distribution of Ukrainian exports in 2000-06, we divide all exports into three main destination categories: EU-OECD, and CEE-CIS and Others. ${ }^{17}$ Next, we modify the propensity score estimation algorithm by adding export destination information and present the estimates of export-related productivity benefits classified by the technology intensity of the industry and export destination.

\section{Learning by Exporting Effect by Industry and Export Destination}

This section explores the differences in the effect of export entry on firm productivity taking into account both the technological intensity of the industry where a firm operates and the characteristics of the target export market. Based on the analysis of the geographical distribution of Ukrainian exports, presented in Section 4.2, we identify the two main global export regions. The first one includes the EU and OECD countries that, according to the UN country classification ${ }^{18}$, are categorized as developed/advanced economies. Following the extant theoretical and empirical literature we expect that penetrating advanced EUOECD markets should result in the strongest export premium, due to the substantial scope for learning and technology improvement. Moreover, the effect should be even stronger in the high technology sectors, characterized by higher knowledge-absorptive capacities. The second export region includes CIS, CEE and Other markets. We expect, that exporting to the countries of CEE and CIS, more similar to Ukraine in terms of economic structure and technology, should result in lower or no productivity benefits. Equally, we do not expect significant productivity gains associated with exporting to Other markets, a category that includes the remaining emerging markets from the rest of the world. Furthermore, due to the industrial structure of the Soviet Union, large part of the exports to other CIS countries may occur as part of the historically established production chain, with little potential productivity spillovers (De Loecker 2007). In summary, the first group of countries represents

\footnotetext{
${ }^{17}$ Note that the residual category "Others" includes only emerging/developing markets.

${ }^{18}$ The latest edition of the UN country classification can be found at: http://www.un.org/en/development/ desa/policy/wesp/wesp_current/2012country_class.pdf
} 
Table 8 Yearly differences in TFP between export entrants and matched non-exporters by destination

\begin{tabular}{llll}
\hline Export premia at time & (a) & (b) & (c) \\
\hline Low-technology firms & & & \\
$\mathrm{t}-1$ & 0.021 & 0.059 & -0.153 \\
$\mathrm{t}$ & $0.393^{* *}$ & $0.252^{*}$ & 0.283 \\
$\mathrm{t}+1$ & $0.550^{* *}$ & 0.214 & $0.412^{*}$ \\
$\mathrm{t}+2$ & $0.545^{* *}$ & $0.361^{* *}$ & $0.554^{*}$ \\
$\mathrm{t}+3$ & $0.595^{* *}$ & $0.385^{* *}$ & -0.151 \\
$\mathrm{t}+4$ & 0.463 & $0.794^{* *}$ & -0.051 \\
Number of Controls & 100 & 136 & 60 \\
Number of Treated & 285 & 405 & 180 \\
& & & \\
High-technology firms & 0.117 & -0.037 & -0.044 \\
$\mathrm{t}-1$ & $0.355^{* *}$ & 0.133 & 0.230 \\
$\mathrm{t}$ & $0.587^{* * *}$ & 0.199 & 0.242 \\
$\mathrm{t}+1$ & $0.651^{* * *}$ & $0.405^{* * *}$ & 0.217 \\
$\mathrm{t}+2$ & $1.136^{* * *}$ & 0.169 & $0.803^{*}$ \\
$\mathrm{t}+3$ & $1.222^{* * *}$ & $0.458^{*}$ & 0.047 \\
$\mathrm{t}+4$ & 88 & 167 & 73 \\
Number of Controls & 264 & 501 & 215 \\
Number of Treated & & & \\
\hline
\end{tabular}

As in Section 4.1, the matching has been quite successful in balancing the differences in the covariates between the treatment and control group. The mean standardized bias over covariates, used in the propensity score estimation, declines from $45-55$ percent before the matching to 3-5 percent after the matching. The pseudo $R^{2}$ reduces from $0.35-0.15$ to almost zero

(a) Entrants into advanced markets; (b) Entrants into the markets of similar or lower development levels; (c) multientrants. The number of treated and controls decreases with $s . *$ - significant at $10 \%$; ** - significant at $5 \% ; * * *$ - significant at $1 \%$

advanced export markets, while the second group includes the markets with similar or lower development levels.

To take into account the multidimensional nature of exports, we distinguish between (a) firms that enter the EU-OECD markets and do not expand to other regions; (b) firms that enter CIS-CEE markets or Other markets and do not expand to other regions; (c) firms that enter CEE-CIS/Other markets and EU-OECD markets at the same time (multientrants). ${ }^{19}$ We do not have any prior with respect to the export entrants that target markets of various development levels at the same time (category c). According to some empirical evidence, export diversification is positively correlated with the productivity of the firm, which should result in stronger export-productivity premia. However, new exporters in this category diversify across emerging and advanced markets, which makes the effect of exports on firm-level productivity difficult to predict.

Having defined the three categories of export entrants, we proceed by redefining the ENTRY variable. We then reapply the matching algorithm, discussed in Section 3.2, separately for the high and low technology exporters belonging to the categories (a)-(c).

\footnotetext{
${ }^{19}$ Other categories contain a much smaller number of firms, which does not allow to obtain reliable estimates.
} 
Table 8 presents the difference in logs of the TFP between export-entrants and their respective matches, in the categories (a)-(c). These estimates represent an approximate percentage effect of export entry on TFP. In line with previous findings, the results reveal a much stronger productivity effect for the exporters that target advanced markets. During the first four years of entry, entrants into these markets in both, high and low technology sectors, show higher levels of TFP relative to matched non-exporters. The productivity premium for these export entrants in the high technology sectors becomes significantly larger over time, increasing from around $35 \%$ in the year of entry $t$ to over $100 \%$ at $t+4$. Such pattern is consistent with the evidence of continuous learning through exports. The productivity premium of the advanced markets export entrants in the low technology sectors is more stable, increasing from $40 \%$ to around $60 \%$ by $t+3$.

The effect of entry into similar or less developed (CIS-CEE or Other) markets, presented in column (b), is lower in magnitude for both categories of firms. Low-tech export entrants in category (b) become on average $25 \%$ more productive than their non-exporting controls in the year of entry. This gap increases to $38 \%$ after three years of exports. At the same time, high-tech export entrants in this category do not show a persistent productivity premium, with spikes only in the third and fifth year.

Finally, all export entrants that target multiple markets at the same time reveal significant export premia in the year of entry. However, this effect is short-lived and does not provide a reliable evidence, consistent with continuous learning through exports.

Note that in some cases the export-related productivity premium becomes insignificant at $t+4$, as the sample size progressively decreases. Furthermore, the productivity premium

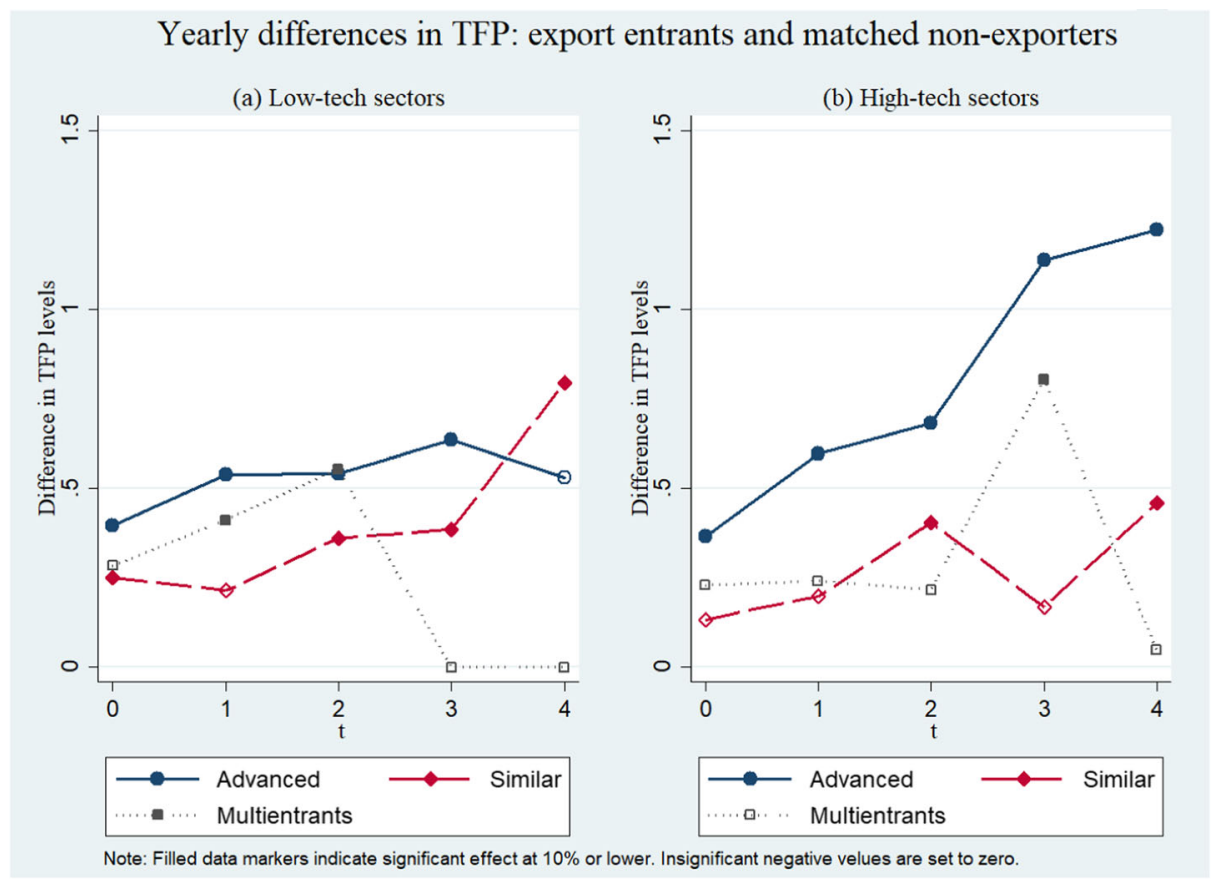

Fig. 2 Yearly differences in TFP: exports and matched non-exports 
obtained at $t+4$ may also overestimate the learning by exporting effect as it compares nonexporters to only persistent exporters. Notice also that at $t-1$ the estimates of difference in productivity levels are close to zero and insignificant for all categories of export entrants, which provides additional support for the validity of our matching procedure.

Figure 2 illustrates the results, presented in Table 8. As discussed earlier, the high technology firms that target advanced markets exhibit the highest export premium in terms of TFP levels. Moreover, the rising productivity gap between these exporters and their matched controls is supportive of the learning through exports hypothesis. In fact, the mean productivity premium for high technology firms that enter advanced markets is also statistically significantly higher (at the $1 \%$ level) than the premia of export entrants in categories (b) and (c).

According to the previous empirical literature, the higher TFP levels of export entrants reported might be driven by a number of factors, other than learning through exports. These factors include the remaining part of the selection bias, increased capacity utilization or economies of scale (Eliasson et al. 2009; De Loecker 2007). However, a progressively widening productivity gap between new exporters in category (a) and their matched controls might be interpreted as a continuous learning through exports. The results, presented in Table 9, confirm this conjecture by presenting the estimates of the differences in the year to year productivity growth rates between export entrants and their non-exporting matches.

Indeed, the estimates of the export-related productivity growth premium reveal that hightech export entrants that target advanced markets grow significantly faster year to year

Table 9 Differences in year to year TFP growth rates between export entrants and matched non-exporters

\begin{tabular}{llll}
\hline Export premia at time & (a) & (b) & (c) \\
\hline Low-technology firms & & & \\
$\mathrm{t}-1$ & -0.167 & -0.014 & 0.049 \\
$\mathrm{t}$ & $0.342^{* * *}$ & $0.192^{* * *}$ & $0.437^{* * *}$ \\
$\mathrm{t}+1$ & $0.192^{* * *}$ & 0.009 & 0.127 \\
$\mathrm{t}+2$ & -0.062 & $0.157^{* * *}$ & $0.219^{* *}$ \\
$\mathrm{t}+3$ & 0.023 & -0.041 & -0.183 \\
$\mathrm{t}+4$ & -0.163 & 0.079 & -0.131 \\
Treated & 100 & 136 & 60 \\
Controls & 285 & 405 & 180 \\
High-technology firms & & & \\
$\mathrm{t}-1$ & -0.039 & -0.036 & 0.046 \\
$\mathrm{t}$ & $0.237^{* * *}$ & $0.171^{* * *}$ & $0.273^{* * *}$ \\
$\mathrm{t}+1$ & $0.218^{* *}$ & $0.112^{* * *}$ & 0.026 \\
$\mathrm{t}+2$ & $0.107^{*}$ & $0.103^{* *}$ & $0.119^{* *}$ \\
$\mathrm{t}+3$ & $0.172^{*}$ & -0.047 & 0.129 \\
$\mathrm{t}+4$ & -0.054 & 0.048 & -0.007 \\
Treated & 88 & 167 & 73 \\
Controls & 264 & 501 & 215 \\
\hline
\end{tabular}

(a) Entrants into advanced markets; (b) Entrants into the markets of similar or lower development levels; (c)

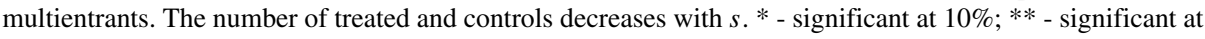
$5 \%$; *** - significant at $1 \%$ 
Yearly differences in TFP growth rates: export entrants and matched non-exporters

(a) Low-tech sectors

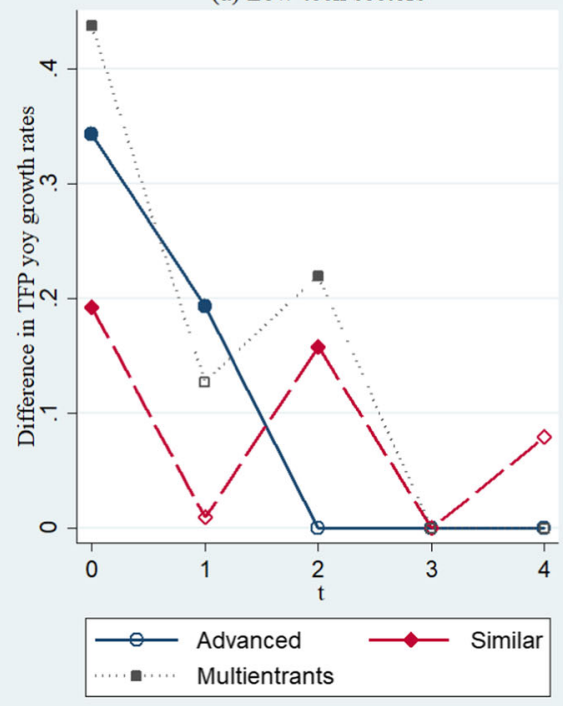

(b) High-tech sectors

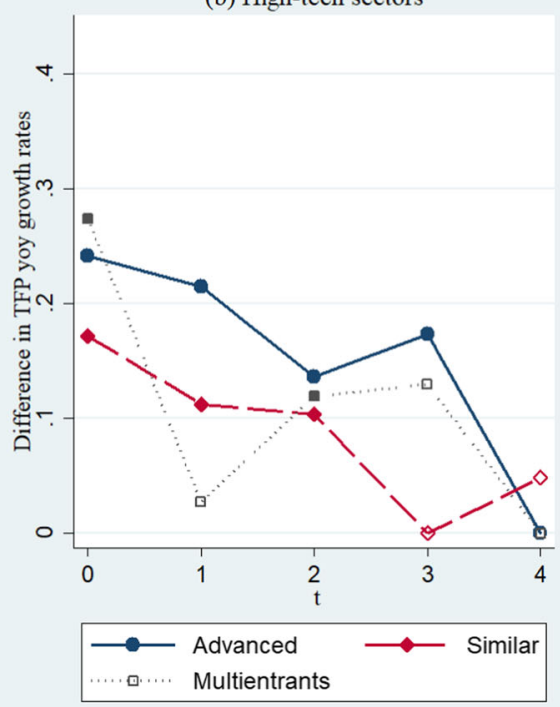

Note: Filled data markets indicate significant effect at $10 \%$ or lower. Insignificant negative values are set to zero.

Fig. 3 Yearly differences in TFP growth rates: export entrants and matched non-exporters

within the first four years of exporting. Four years after entry, this group still grows $17 \%$ faster with respect to their controls. On the other hand, low-tech advanced markets entrants grow significantly faster only in the first two years of exports. At the same time, the productivity growth premium for low-tech export entrants in category (b) is only significant in the first and third year upon entry (19\% and $15 \%$ respectively), while the growth premium for the high-tech export entrants in this category is significant during the first three years of exports: declining from $17 \%$ at $t$ and $10 \%$ at $t+2$. Finally, the dynamics of the productivity growth premia for new exporters that target multiple export regions is very similar to the one of the export entrants in category (b). Overall, the dynamics of export-productivity premia in the last two categories does not seem consistent with a continuous learning through exports.

The illustrative summary of the results is presented in Fig. 3, confirming the productivity growth premium for the new exporters in the high-tech sectors that target advanced markets. These premia range between 17 and $23 \%$ in the first four years of exports, consistently with the learning by exporting effect. Finally, it should be noted that high-tech exporters in all categories (Fig. 3, panel b) exhibit more durable and stable productivity growth premium when compared to the new exporters in the low technology sectors (Fig. 3, panel a).

Table 10, presents the results obtained by using the DID matching estimator (8) that calculates difference in the productivity growth rates with respect to the pre-export levels between new exporters and their respective matches. As discussed in Section 3.1 the DID matching estimator significantly improves the quality of evaluation in the studies based on non-experimental data as it addresses potential sources of temporally invariant bias, discrepancy in the measurement conventions and the effects of common shocks, providing us 
Table 10 Differences in TFP growth rates between export entrants and matched non-exporters with respect to the pre-export levels

\begin{tabular}{llll}
\hline Export premia at time & (a) & (b) & (c) \\
\hline Low-technology firms & & & \\
$\mathrm{t}$ & $0.372^{* * *}$ & $0.192^{* * *}$ & $0.437^{* * *}$ \\
$\mathrm{t}+1$ & $0.529^{* * *}$ & $0.154^{* * *}$ & $0.566^{* * *}$ \\
$\mathrm{t}+2$ & $0.527^{* * *}$ & $0.294^{* * *}$ & $0.807^{* * *}$ \\
$\mathrm{t}+3$ & $0.253^{* *}$ & $0.170^{*}$ & 0.180 \\
$\mathrm{t}+4$ & -0.067 & $0.386^{* *}$ & 0.091 \\
Treated & 100 & 136 & 60 \\
Controls & 285 & 405 & 180 \\
High-technology firms & & & \\
$\mathrm{t}$ & $0.237^{* * *}$ & $0.171^{* * *}$ & $0.273^{* * *}$ \\
$\mathrm{t}+1$ & $0.469^{* * *}$ & $0.237^{* * *}$ & $0.285^{* *}$ \\
$\mathrm{t}+2$ & $0.545^{* * *}$ & $0.427^{* * *}$ & $0.286^{* *}$ \\
$\mathrm{t}+3$ & $1.051^{* * *}$ & 0.145 & $0.446^{* *}$ \\
$\mathrm{t}+4$ & $0.918^{* * *}$ & $0.777^{* * *}$ & $0.495^{* * *}$ \\
Treated & 88 & 167 & 73 \\
Controls & 264 & 501 & 215 \\
\hline
\end{tabular}

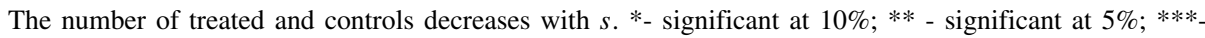
significant at $1 \%$

with more reliable estimates of the treatment effect. The results of the DID matching estimator, in line with De Loecker (2007), reveal a positive and significant effect of exporting on productivity, for all categories of exporters.

Consistent with previous estimates, presented in Tables 8-9, export entrants that target advanced export regions grow consistently significantly more than their matches with respect to the corresponding pre-export levels. Furthermore, the productivity growth premia for high technology exporters in this category become significantly wider over time, increasing from $24 \%$ at $t$ to $105 \%$ at $t+4$. Low-tech entrants into advanced market grow on average $37 \%$ faster than their matched controls with respect to pre-export productivity levels at $t$ and only $25 \%$ faster at $t+4$.

New high-tech exporters entering similar or less developed markets reveal a shorter and smaller in magnitude export premium: on average they grow $17 \%$ faster than their matches with respect to $t-1$ in the year of entry and this premium rises to $77 \%$ four years into exporting. The low-technology export entrants in this category reveal similar results: their export-productivity premium is ranging from $19 \%$ in the year of entry to $38 \%$ four years after.

Finally, the export premium for the last category of firms - entrants into multiple markets - seems to be stronger for the high-technology exporters. High-tech export entrants in this category grow on average $27 \%$ faster at $t$ (with respect to $t-1$ ), and this premium widens to $49 \%$ at $t+4$. On the other hand, low-tech multientrants experience a strong productivity effect only in the first two years after entry.

The summary of the results, presented in Fig. 4, in line with the findings presented in Tables 8-9, confirms that the estimates for the high-tech export entrants into advanced markets are consistent with the learning by exporting effect. 
Differences in TFP growth rates to t-1: export entrants and matched non-exporters

(a) Low-tech sectors

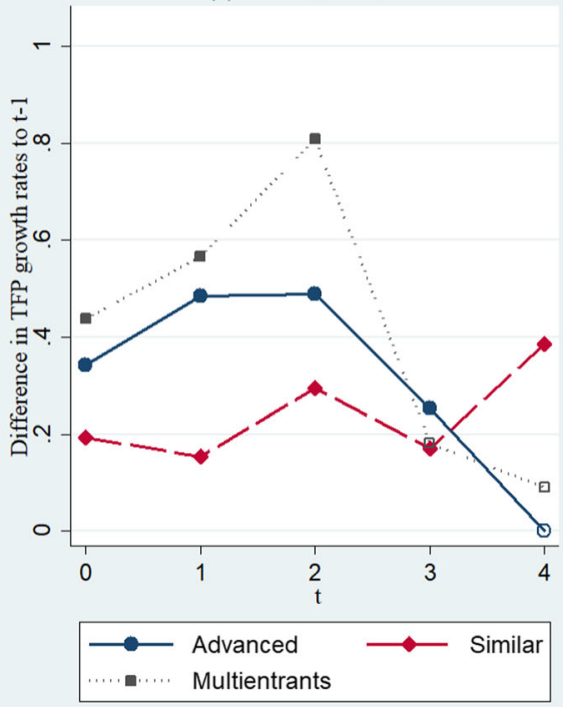

(b) High-tech sectors

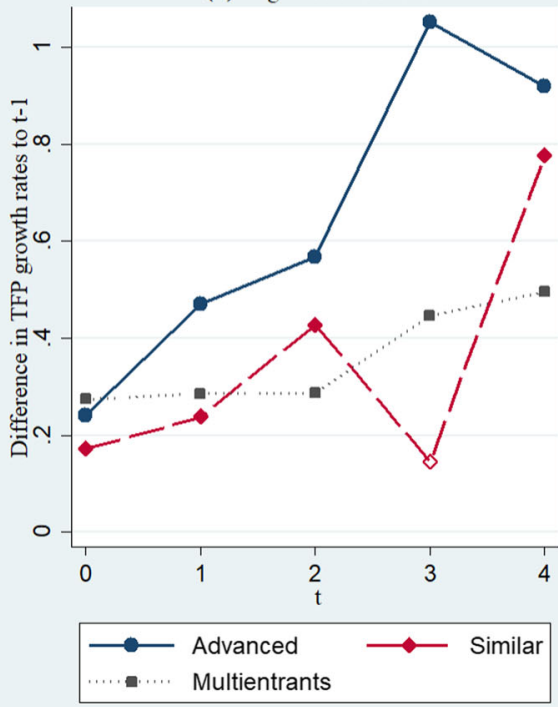

Note: Filled data markers indicate significant effect at $10 \%$ or lower. Insignificant negative values are set to zero.

Fig. 4 Differences in TFP growth rates to t-1: export entrants and matched non-exporters

Indeed, as shown in Fig. 4 panel (b), export entrants that target advanced markets reveal a widening gap in terms of pre - post entry productivity growth differences. Furthermore, the mean export premium of high-tech firms that enter advanced markets is statistically significantly higher (at $1 \%$ level) than the one of export entrants in other categories.

Overall, the main findings presented in this section indicate that the heterogeneity of the learning-by-exporting effects may be explained by the industry technological intensity combined with the specific characteristics of export destinations. In line with Damijan et al. (2004), De Loecker (2007) and Silva et al. (2012b) our results indicate stronger exportrelated productivity benefits when exports are aimed at relatively more advanced markets due to higher competitive pressure and more knowledge spillovers. Moreover, adding to the extant literature, we find that effects of learning through exports to advanced markets are significantly stronger and more persistent for firms operating in high technology sectors. The magnitude of the export-related productivity premia in this paper, higher than other contributions in the literature (e.g. De Loecker 2007), may be at least partially explained by the specific time period and characteristics of the country under study. During 200006 Ukraine was still classified as a transition economy, with most industries operating below the world technology frontier. As a result Ukrainian exporters, exposed to advanced Western markets, had to compete with firms that used the latest technologies and best management practices. This fact, logically, implied significant scope for learning and productivity improvement. Finally, as suggested by Aw et al. (2000), a widening productivity gap between new exporters and domestic producers might not reflect direct benefits from exporting. Instead, such a gap may result from other factors that lead to a positive serial correlation in the firm productivity shocks. Firms with positive productivity shocks are more 
likely to transit into exporting. If these persist, the productivity premium of these producers will widen over time. However, the patterns of post-entry productivity changes, documented in this paper, are consistent with the productivity gains that accrue from the exporting process.

\section{Robustness Checks}

The main results, presented in the last section, have shown that starting to export is associated with productivity improvements. The highest gains are recorded for first time export entrants, in high technology sectors that enter advanced markets. In this section we assess the robustness of these conclusions to a number of methodological issues.

\subsection{Sample Choice}

The matching methodology, implemented in this paper, compares all export entrants to the firms that never exported during the period of study, 2000-06. Some of the firms used as controls in the current study might commence their exporting activity in later periods not covered by our dataset, in which case we are comparing export entrants to potential export entrants, introducing a downward bias to our estimates. The productivity effect of export entry might also be driven by persistent new exporters, known as export successes, while the firms that cease exporting after a couple of years might exhibit no productivity improvements associated with exporting activity. To check the sensitivity of our results to the sample used in the current study, we present the estimates of the difference in the productivity growth to pre-export levels (DID matching estimator) between new exporters and matched non-exporters separately for the firms that stay for two, three, four, five and six years in exporting (De Loecker 2007).

The results, presented in Table 11, indicate an insignificant productivity effect for the firms exiting after one year of export (failures) and a weaker effect for the firms that stay in exporting for two years only. However, for the rest of the groups, the results at each period $t$ tend to be significant and quantitatively similar. For example, at $t=2$ the productivity gain with respect to pre-export levels for the firms with three consecutive years of exports

Table 11 Productivity growth to pre-export levels $(t-1)$ : detailed results

\begin{tabular}{|c|c|c|c|c|c|c|}
\hline $\mathrm{t}$ & 0 & 1 & 2 & 3 & 4 & 5 \\
\hline \multicolumn{7}{|c|}{ Consecutive years in exporting since entry } \\
\hline 6 & $0.151 * * *$ & $0.352 * * *$ & $0.382 * * *$ & $0.382 * * *$ & $0.438 * * *$ & $0.358 * * *$ \\
\hline 5 & $0.126 * * *$ & $0.155 * * *$ & $0.217 * * *$ & $0.221 * *$ & $0.243 * * *$ & \\
\hline 4 & $0.261 * * *$ & $0.380 * * *$ & $0.398 * * *$ & $0.406^{* * * *}$ & & \\
\hline 3 & $0.353 * * *$ & $0.376 * * *$ & $0.540 * * *$ & & & \\
\hline 2 & $0.228 * *$ & 0.175 & & & & \\
\hline 1 & 0.474 & & & & & \\
\hline
\end{tabular}

The first column indicates the number of years the firms stay in exporting. For example, the first raw compares the firms that entered export markets in 2001 and stayed in exporting until 2006 inclusive, while the last row compares the firms that managed to stay in exporting for one year only. * - significant at $10 \%$; ** significant at $5 \%$; ***- significant at $1 \%$ 
is $54 \%$, while for firms with four consecutive years of exports, the gain is around $40 \%$. Overall, the results above confirm that the estimated productivity premia are not driven by any specific sample of firms.

Finally, to provide out of sample validation to our procedure we have randomly split the sample in half across sectors and implemented the matching procedure separately for the two random sub-samples of firms. The results obtained by using both cross-sectional and DID propensity score matching estimators show no statistical difference across the two sub-samples.

\subsection{Aggregate Shocks}

The significant productivity gains of new exporters, documented in our analysis, might also be driven by aggregate exogenous shocks occurring in the years following export entrance. To verify the sensitivity of our results to these shocks we adopt a regression-based approach that tests the effect of export entry on productivity, taking into account year and industry fixed effects occurring in the post-entry period. We use the panel structure of the data and estimate the following OLS regression on a sample of matched firms:

$$
\begin{aligned}
\ln T F P_{i t+s}-\ln T F P_{i t-1}= & \alpha_{0}+\beta_{t+s} E X P_{i t}+\sum_{s} \gamma_{t+s} Y E A R_{t+s} \\
& +\sum_{k} \rho_{k} I N D_{k}+\sum_{k} \sum_{s} \phi_{k t+s} I N D_{k} * Y E A R_{t+s}+\xi_{i t+s}
\end{aligned}
$$

In Eq. 9 the dependent variable represents the difference of $\ln T F P_{i t+s}$ to its value before the treatment (export entry), $\ln T F P_{i t-1}$. EX $P_{i t}$ takes value one when a firm starts to export and zero otherwise. $Y E A R_{t+s}$ and $I N D_{k}$ are year and industry fixed effects that should capture aggregate shocks in the post-entry period. $\xi_{i t+s}$ is an i.i.d. error term. Hence, $\beta_{t+s}$ should reflect the difference in the productivity growth rate before (at $t-1$ ) and after (at $t+s$ ) the treatment (export entry) between export entrants and non-exporters. If additional control variables are excluded from the Eq. 9 , the estimates of the $\beta_{t+s}$ should be equivalent to the ones obtained using the DID propensity score matching estimator (8). Similar to the DID propensity score matching estimator, this approach eliminates firm-level fixed effects, taking care of the time-invariant portion of the selection bias that might remain after the matching. Finally, the regression-based approach accounts for various factors, such as year and industry shocks, that might affect firm productivity in the post entry period, not captured by the DID matching estimator (8) (Pisu 2008).

The results presented in column (c) of Table 12, confirm that entering export markets is associated with faster productivity growth with respect to pre-export levels. Overall, the results, are very similar to the ones obtained using the DID propensity score matching estimator (Table 4, column (c)).

The results presented in columns (a) and (b) are obtained by running the regressions similar to Eq. 9 with the $\ln T F P_{i t+s}$ and $\ln T F P_{i t+s}-\ln T F P_{i t+s-1}$ as dependent variables. ${ }^{20}$ These results should be compared to the estimates of the yearly differences in productivity levels and growth rates between the new exporters and their non-exporting counterparts (Table 4, columns (a) and (b)). Again, the results prove to be very similar to the ones obtained using the CS propensity score matching estimator.

\footnotetext{
${ }^{20}$ Note that the regression in column (a) includes time invariant firm-level fixed effects.
} 
Table 12 Productivity differentials: estimates on the matched sample

\begin{tabular}{llll}
\hline & (a) & (b) & (c) \\
\hline$t$ & $0.267^{* * *}$ & $0.244^{* * *}$ & $0.246^{* * *}$ \\
$t+1$ & $0.352^{* * *}$ & $0.112^{* * *}$ & $0.354^{* * *}$ \\
$t+2$ & $0.455^{* * *}$ & $0.101^{* * *}$ & $0.462^{* * *}$ \\
$t+3$ & $0.409 * * *$ & $0.016^{* * *}$ & $0.456^{* * *}$ \\
$t+4$ & $0.356^{* * *}$ & $0.025^{* * *}$ & $0.343^{* * *}$ \\
Industry & Yes & Yes & Yes \\
Year & Yes & Yes & Yes \\
Industry\#Year & Yes & Yes & Yes \\
\hline
\end{tabular}

Regressions were run with robust standard errors. $*$ - significant at $10 \%$; ** - significant at $5 \%$; ***significant at $1 \%$

\subsection{Size}

A number of studies on export-productivity links conclude that export-related productivity benefits might differ for firms of different sizes (Eliasson et al. 2009; Damijan and Kostevc 2015; Silva et al. 2012b). In order to verify this conjecture, we have implemented a separate matching procedure for three subsets of firms in our data: (i) firms with less than 20 employees (small firms); (2) firms between 20 and 50 employees (medium size firms); (3) firms with more than 50 employees (large firms). The results of the cross-sectional and DID matching estimators indicate that all three subsets of firms enjoy significant positive exportrelated productivity benefits. However, in line with Eliasson et al. (2009); and Damijan and Kostevc (2015), the effect seems to be more pronounced for small and medium firms. ${ }^{21}$

\subsection{Alternative Productivity Measure}

Finally, we performed the matching procedure using value added per employee as an alternative measure of firm productivity. The results of the cross-sectional and DID matching estimators based on this alternative productivity measure are very similar to the main results of the paper, supporting the robustness of our findings. A slight difference in the results only arises in terms of the cross-sectional matching estimator, which assesses the differences in TFP levels between new exporters and matched non-entrants in the high technology sectors. The results indicate that the export-related benefits for the high-tech entrants into similar or less developed markets are slightly more persistent in terms of labor productivity than they are in terms of TFP. The rest of the results based on differences in year-on-year TFP growth rates and differences in TFP growth rates with respect to respective pre-export TFP levels are very similar to our main findings both in terms of magnitude and duration of the effects. $^{22}$

\footnotetext{
${ }^{21}$ The results of the cross-sectional and DID matching estimators for different size groups are available upon request.

${ }^{22}$ The results of the cross-sectional and DID matching estimators using value added per employee are available upon request.
} 


\section{Concluding Remarks}

This paper aims to study the joint role of destination and industry characteristics in the post-entry productivity benefits of new exporters. The empirical evidence on the learning by exporting effect is still not fully conclusive and indicates two main sources of heterogeneity: destination and firms' characteristics. The main contribution of this paper is then to empirically assess the joint role of these two factors in firms' export-related productivity benefits.

To explore the above conjecture, we used a rich micro-level dataset of Ukrainian manufacturing firms over the period 2000-06. First, we verified the technological intensity of each industry, using the Hatzichronoglou (1997) approach, and classified them into low and high technology. Then, we obtained TFP estimates using a modified version of the Olley and Pakes (1996) methodology, controlling for demand shocks and different market structures for exporting and non-exporting firms. After, we implemented the propensity score matching methodology, separately for firms that enter: (a) advanced markets; (b) markets of similar or lower development level; (c) advanced and similar markets at the same time. Having obtained a counterfactual control group, we estimated the post-entry productivity gains associated with the exporting process, using cross-sectional and difference-in-differences versions of the matching estimator. Finally, we implemented a number of robustness checks that support the validity of our findings.

The results of the analysis confirm a significant rise in productivity gains for new exporters. On average, these firms become $24.5 \%$ more productive in the year of entry with a stable positive productivity gap in the following years. Furthermore, during the entry year new exporters grow $22.7 \%$ faster with respect to domestic producers. However, this growth premium reduces over time falling to $2.8 \%$ four years into exporting. At the same time, only new exporters operating in high technology sectors that target advanced markets experience a significant long-term productivity growth premium. On average these firms become $35 \%$ more productive in the year of entry and their annual productivity gap widens to $122 \%$ five years into exporting. This result is supported by the year-to-year productivity growth premium for this type of firms, as they grow on average 18\% faster than domestic producers during the first four years of exports. Finally, the results obtained using the DID matching estimator, show that these firms become progressively more productive than domestic producers with respect to their pre-export productivity levels. Overall, the evidence on high-tech firms targeting advanced markets is consistent with learning through export, as witnessed by the widening productivity gap. On the other hand, firms in low technology sectors tend to experience a stronger productivity shock in the first year of entry across all export destinations. However, their export-productivity premia tend to be shortlived, indicating that such results might be driven by increased capacity utilization and the use of the economies of scale rather than by export-related productivity improvements.

The results of this study may have relevant implications for policy makers, particularly in transition and developing economies. Indeed, many developing countries employ industrial and export promoting policies. In particular, industrial policies in these countries often target R\&D investment and the development of technology-intensive sectors, whereas export-promoting policies include direct export subsidies, low-cost loans and tax reliefs for exporters. The results of this study suggest that better tailoring those policies is likely to enhance their effectiveness. In fact, new exporters in technology intensive sectors exhibit higher potential to improve their productivity and possibly innovativeness through exports. The latter effect is more pronounced for firms exporting to relatively more developed countries. Thus, tailoring industrial and export-promoting policies specifically toward 
high-tech firms serving advanced economies is likely to make government interventions more effective and result in stronger sectoral and aggregate productivity growth.

Open Access This article is distributed under the terms of the Creative Commons Attribution 4.0 International License (http://creativecommons.org/licenses/by/4.0/), which permits unrestricted use, distribution, and reproduction in any medium, provided you give appropriate credit to the original author(s) and the source, provide a link to the Creative Commons license, and indicate if changes were made.

\section{Appendix A: Number of Firms, Average Size and Share of Exporters by Industry}

Table 13 Number of firms, average size and share of exporters by industry

\begin{tabular}{lllll}
\hline Industry & N firms & N exporters & Average size & \% exporters \\
\hline Food \& Beverages & 11022 & 1587 & 60 & 14 \\
Textile, leather, apparel & 5640 & 849 & 58 & 15 \\
Wood \& paper & 5702 & 1281 & 35 & 22 \\
Printing \& publishing & 7229 & 1224 & 12 & 17 \\
Coke \& chemistry & 2381 & 587 & 125 & 25 \\
Rubber \& plastic & 2249 & 401 & 26 & 18 \\
Non-metallic minerals & 3997 & 633 & 66 & 16 \\
Metallurgy \& basic metals & 4472 & 827 & 108 & 18 \\
Machinery \& equipment & 6400 & 1321 & 77 & 21 \\
High-tech machinery & 5731 & 994 & 51 & 17 \\
Motor vehicles, trailers & 1501 & 441 & 136 & 29 \\
Furniture/Manufacturing n.e.c. & 4706 & 684 & 26 & 15 \\
Total & 61030 & 10829 & & 19 \\
Mean & 5086 & 902 & 65 & \\
\hline
\end{tabular}

\section{Appendix B: Market Structure and Production Function}

We start by assuming a standard Cobb-Douglas production function of a single-product firm $i$ at time $t$ producing output $Y_{i t}$ using labor $\left(L_{i t}\right)$, capital $\left(K_{i t}\right)$ and intermediate inputs $\left(M_{i t}\right)$ :

$$
Y_{i t}=L_{i t}^{\alpha_{l}} K_{i t}^{\alpha_{k}} M_{i t}^{\alpha_{m}} \exp \left(\omega_{i t}+u_{i t}\right),
$$

where $\omega_{i t}$ is a firm-specific productivity component that subsumes a constant term and $u_{i t}$ subsumes an idiosyncratic production shock and measurement errors.

Very often the data on physical output is not available, so most of the studies rely on firm sales (revenue) $R_{i t}=P_{i t} Y_{i t}$ or value added when estimating production function parameters. At the same time, $R_{i t}$ may reflect differences in firm mark-ups and correlation between intermediate inputs and unobserved firm-level prices. Hence, relying on $R_{i t}$ when estimating production function parameters may result in productivity estimates that capture price and demand variation. To clean the estimates from variation in prices and demand shocks, we follow De Loecker (2011) and introduce a standard horizontal product differentiation demand system (CES) for a firm $i$ operating in industry $s$ :

$$
Y_{i t}=Y_{s t}\left(\frac{P_{i t}}{P_{s t}}\right)^{\eta_{s}} \exp \left(\xi_{i t}\right)
$$


Equation 11 conjectures that demand for a firm output $Y_{i t}$ depends on the aggregate demand shifter that is represented by the total product demand in a specific industry in a relevant market $Y_{s t}$, firm-specific prices $P_{i t}$ and industry average price $P_{s t}$ and $\xi_{i t}$, an unobserved demand shock correlated with price and observed demand shifter (De Loecker 2011; Shepotylo and Vakhitov 2015)

The demand system (11) can now be used to obtain the expression for the price $P_{i t}$ (Klette and Griliches 1996; Levinsohn and Melitz 2002; De Loecker 2011). The firm revenue can be expressed as $R_{i t}=P_{i t} Y_{i t}$, and, using the expression for the price derived from Eq. 11, as follows:

$$
R_{i t}=\left(Y_{i t}\right)^{\frac{\eta_{s}+1}{\eta_{s}}}\left(Y_{s t}\right)^{-\frac{1}{\eta_{s}}} P_{s t}\left(\exp \left(\xi_{i t}\right)\right)^{-\frac{1}{\eta_{s}}}
$$

Finally, using $Y_{i t}$ from Eq. 11, plugging it into Eq. 12, dividing both sides by $P_{s t}$ and taking $\log$ s results in:

$$
r_{i t}=\beta_{l} l_{i t}+\beta_{k} k_{i t}+\beta_{m} m_{i t}+\beta_{y} y_{s t}+\omega_{i t}^{*}+\xi_{i t}^{*}+u_{i t}^{*},
$$

where the lower-case letters represent the natural logs of the upper case variables and $r_{i t}=$ $\ln \left(\frac{R_{i t}}{P_{s t}}\right)$ is a natural logarithm of revenue deflated by the corresponding industry-specific price deflator. The estimated parameters are $\beta_{h}=\left(\frac{\eta_{s}+1}{\eta_{s}}\right) \alpha_{h}$ for $h=\{l, k, m\} . \beta_{y}=-\frac{1}{\eta_{s}}$ and the industry elasticity of substitution can be recovered as $\eta_{s}=-\frac{1}{\beta_{y}}$. Finally, the error terms are: $\omega_{i t}^{*}=\frac{\eta_{s}+1}{\eta_{s}} \omega_{i t}, \xi_{i t}^{*}=-\frac{1}{\eta_{s}} \xi_{i t}, u_{i t}^{*}=\frac{\eta_{s}+1}{\eta_{s}} u_{i t}$.

We proceed by estimating (13) separately for all two-digit manufacturing industries (NACE classification). ${ }^{23}$ Sales, capital and intermediate inputs are deflated using the industry-wide Producer Price Index which, assuming competitive input markets, should not bias the production function parameter estimates. Also, relying on the assumption of constant elasticity of substitution within a two-digit industry $s$, we use a 4-digit sub-industry output $g \in s$ to add more variability to the estimation of $\eta_{s}$ (Shepotylo and Vakhitov 2015). The overall demand shock for sub-industry $g$ can be decomposed into three components:

$$
\xi_{\text {git }}=\xi_{g t}+\xi_{g}+\xi_{\text {it }}
$$

with $\xi_{g t}$ being an sub-industry-wide shock common to all incumbent firms at time $t, \xi_{g}$ demand shock affecting only firms operating in sub-industry $g$, and $\xi_{i t}$ - remaining shock i.i.d. across producers and time. After plugging in Eq. 14 into Eq. 13 we derive the following revenue production function:

$$
r_{i t}=\beta_{l} l_{i t}+\beta_{k} k_{i t}+\beta_{m} m_{i t}+\beta_{y} y_{g t}+\delta_{t} D_{t}+\delta_{g} D_{g}+\omega_{i t}^{*}+\xi_{i t}+u_{i t}^{*},
$$

where $D_{t}$ is a time fixed effect, $D_{g}$ sub-industry fixed effect and both $\xi_{i t}$ and $u_{i t}^{*}$ represent error terms i.i.d. across producers and time and not correlated with production inputs or productivity. Thus, Eq. 15 can be used to recover the TFP estimates net of price and demand shocks.

\section{Appendix C: Productivity Estimation Algorithm}

Having derived the modified revenue function (15) that takes into account industry-specific price and demand shocks (De Loecker 2011; Shepotylo and Vakhitov 2015) we obtain the

\footnotetext{
${ }^{23}$ We suppress the sector index $s$ for presentation clarity.
} 
estimates of the firm-level total factor productivity by implementing a modified version of the Olley and Pakes (1996) algorithm that allows for different market structures and factor prices for exporting and non-exporting firms. The difference between operating conditions for exporters and non-exporters is identified by adding export status information to the investment function in the Olley and Pakes (1996) algorithm. ${ }^{24}$

As in the original model we assume that productivity follows an exogenous first-order Markov process $\omega_{i t}=E\left(\omega_{i t} \mid \omega_{i t-1}\right)+\xi_{i t}$, where productivity $\omega_{i t}$ at time $t$ represents expected productivity, given a firm's information set $I_{i t}$ that includes past productivity $\omega_{i t-1}$ and a productivity shock $\xi_{i t}$.

Every period a firm has to make a decision to stay or leave the market and, conditional on staying, it has to decide on the allocation of labor $(l)$, materials $(m)$ and investment $(i)$. The choice of investment determines the stock of capital in the beginning of each period and features in the law of capital accumulation given by $k_{i t}=(1-\delta) k_{i t-1}+i_{i t-1}$ with $i_{i t-1}$ being the $\log$ of investment at time $t-1$. The information set $I_{i t}$ defines a firm's perception of the distribution of the future market structure and impacts its exit and investment decision that will, in turn, generate a distribution for the future market structure.

To take into account the fact that exporting firms face different market structures and factor prices when taking their exit and investment decisions, We modify the investment function to include export status: the coefficients of the polynomial $h($.) in Eq. 16 now differ for the exporting firms by the subscript ex. The equilibrium investment function can now be presented as follows:

$$
i_{i t}=i_{e x, t}\left(\omega_{i t}, k_{i t}\right) \Longleftrightarrow \omega_{i t}=h_{e x, t}\left(i_{i t}, k_{i t}\right),
$$

where $e x$ is a dummy indicating firm export status. ${ }^{25}$

Now, we can plug Eq. 16 into the revenue production function defined in Eq. 15 to obtain:

$$
r_{i t}=\beta_{l} l_{i t}+\beta_{m} m_{i t}+\beta_{y} y_{g t}+\delta_{t} D_{t}+\delta_{g} D_{g}+g_{e x, t}\left(k_{i t}, i_{i t}\right)+u_{i t}^{*},
$$

where: $g_{e x, t}\left(k_{i t}, i_{i t}\right)=\left(\frac{\eta_{s}+1}{\eta_{s}}\right)\left(\beta_{k} k_{i t}+h_{e x, t}\left(\omega_{i t}, k_{i t}\right)\right)$.

The probability of survival estimated in stage two of the Olley-Pakes procedure now also takes into account firm export status via the previous period productivity shock and via investment in the capital accumulation process. Indeed, the higher capital-intensity of the exporting firms allows them to stay active with lower productivity shocks relatively to their non-exporting rivals:

$$
\operatorname{Pr}\left\{\chi_{i t}=1 \mid I_{t}\right\}=\operatorname{Pr}\left\{\chi_{i t}=1 \mid \omega_{t-1}, \omega_{i}\left(k_{i t}\right)\right\}=p_{\text {ex }, t}\left(i_{i t-1,} k_{i t-1}\right)=\Pi_{i t}
$$

The last stage to recover the capital coefficient along with the export status dummy can now be implemented by applying a nonlinear least square or GMM estimator on the following equation:

$$
E\left[r_{i t} \mid I_{i t}, \chi_{i t}=1\right]=\beta_{l} l_{i t}+\beta_{m} m_{i t}+\beta_{k} k_{i t}+\beta_{y} y_{g t}+\delta_{t} D_{t}+\delta_{g} D_{g}+\varphi\left(\left(g_{e x, t-1}-\beta_{k} k_{i t-1}\right), \widehat{\Pi}_{i t}\right),
$$

where $\varphi\left(\left(g_{e x, t}-\beta_{k} k_{i t}\right), \widehat{\Pi}_{i t}\right)$ is approximated by the predicted probability of survival from Eq. 18 and a second degree linear approximation of $\omega_{i t-1}=g_{e x, t-1}-\beta_{k} k_{i t-1}=$ $h_{e x, t-1}\left(\omega_{i t-1}, k_{i t-1}\right) .^{26}$

\footnotetext{
${ }^{24}$ The assumptions related to the production function and market structure are presented in Appendix B.

${ }^{25}$ The possibility of accommodating various types of exporters characteristics, such as export experience or the share of exports in total sales in the investment function is discussed in De Loecker (2013).

${ }^{26}$ We refer to Yasar et al. (2008), De Loecker (2007, 2011), Ornaghi and Van Beveren (2012) and Shepotylo and Vakhitov (2015) for further discussion of the OP estimation algorithm.
} 
The final total factor productivity estimates are obtained as:

$$
\omega_{i t}=\left(r_{i t}-\beta_{l} l_{i t}-\beta_{k} k_{i t}-\beta_{m} m_{i t}-\beta_{y} y_{g t}-\delta_{t} D_{t}-\delta_{g} D_{g}\right) \frac{\eta_{s}}{\eta_{s}+1},
$$

where $\beta_{l}, \beta_{k}, \beta_{m}, \beta_{y}$, are the modified Olley-Pakes estimators for labor, capital, material inputs and sub-industry demand.

As discussed in De Loecker (2007), controlling for the export status would solve the problem of the overestimated labor coefficient in the production function and control for the bias in the capital coefficient that may arise due to the higher capital-intensity of exporters. The obtained measures of TFP estimates may still be biased due to measurement errors ${ }^{27}$ and imperfect competition in factor markets. However, if the bias due to the imperfectly competitive factor markets is the same within an industry, it is differenced out when applying the DID matching estimator to estimate the learning-by-exporting effect. The final caveat of the Olley-Pakes estimation procedure is the requirement for positive investment in every period. However, following Pavcnik (2002) and De Loecker (2007) we tried using restricted (firms with only positive investment each period) and unrestricted sample (all firms) with no significant changes in the results. Hence, we have implemented the analysis presented in this paper on the unrestricted sample of firms.

\section{Appendix D: Industry Specific Results}

Table 14 Yearly differences in TFP levels between export entrants and matched non-exporters

\begin{tabular}{|c|c|c|c|c|c|c|}
\hline Industry & $\mathrm{t}-1$ & $\mathrm{t}$ & $\mathrm{t}+1$ & $\mathrm{t}+2$ & $\mathrm{t}+3$ & $\mathrm{t}+4$ \\
\hline Food \& beverages & -0.061 & 0.048 & $0.176^{* * *}$ & $0.345^{* * *}$ & $0.256 * * *$ & $0.307 * * *$ \\
\hline Textile, leather, apparel & 0.243 & 0.535 & $0.774 * *$ & $0.737 * *$ & $1.608 * * *$ & 0.789 \\
\hline Wood \& paper & $0.351 *$ & $0.799 * * *$ & $0.836^{* * * *}$ & $0.771 * * *$ & $0.643 * *$ & 1.043 \\
\hline Printing \& publishing & 0.072 & 0.088 & 0.137 & 0.076 & 0.151 & 0.178 \\
\hline Coke \& chemistry & -0.036 & 0.129 & 0.108 & 0.253 & 0.242 & 0.392 \\
\hline Rubber \& plastic & 0.036 & $0.367 * *$ & $0.491 * *$ & $0.553 * * *$ & 0.395 & $0.354 * *$ \\
\hline Non-metallic minerals & -0.059 & 0.093 & 0.090 & 0.137 & 0.000 & -0.093 \\
\hline Metallurgy \& basic metals & 0.075 & $0.381 * * *$ & $0.459 * * *$ & $0.595 * * *$ & $0.519 * * *$ & $0.521 * *$ \\
\hline Machinery \& equipment & -0.016 & $0.268 * * *$ & $0.302 * * *$ & $0.354 * * *$ & $0.237 * *$ & $0.191 *$ \\
\hline High-tech machinery & 0.075 & $0.280^{*}$ & $0.273^{*}$ & 0.191 & $0.427^{*}$ & 0.155 \\
\hline Motor vehicles, trailers & 0.118 & 0.287 & $0.424 *$ & $0.491 *$ & 0.447 & 0.024 \\
\hline Furniture/Manufacturing n.e.c. & $0.236^{*}$ & $0.431 * * *$ & $0.608 * * *$ & $0.580 * * *$ & $0.268 * *$ & 0.215 \\
\hline Total number of treated & 844 & 844 & 789 & 784 & 570 & 310 \\
\hline Total number of controls & 1,918 & 1,949 & 1,794 & 1,665 & 1,294 & 644 \\
\hline
\end{tabular}

The number of treated and controls decreases with $s . *$ - significant at $10 \%$; ** - significant at $5 \%$; *** significant at $1 \%$

\footnotetext{
${ }^{27}$ At the same time, Van Biesebroeck (2007) shows that semiparametric production function estimators are the least sensitive to measurement errors.
} 
Table 15 Differences in year-to-year TFP growth rates between export entrants and matched non-exporters

\begin{tabular}{lllllll}
\hline Industry & $\mathrm{t}-1$ & $\mathrm{t}$ & $\mathrm{t}+1$ & $\mathrm{t}+2$ & $\mathrm{t}+3$ & $\mathrm{t}+4$ \\
\hline Food \& beverages & -0.029 & $0.109 * * *$ & $0.132 * * *$ & $0.206 * * *$ & -0.028 & -0.019 \\
Textile, leather, apparel & -0.116 & $0.291^{* *}$ & $0.230^{* * *}$ & 0.037 & 0.256 & 0.282 \\
Wood \& paper & -0.106 & $0.447 * * *$ & $0.142 * *$ & -0.047 & $0.311^{*}$ & -0.142 \\
Printing \& publishing & -0.233 & -0.033 & -0.046 & 0.131 & 0.077 & 0.653 \\
Coke \& chemistry & 0.062 & $0.167 * *$ & 0.005 & $0.136^{* *}$ & 0.059 & 0.131 \\
Rubber \& plastic & -0.021 & $0.330^{* * *}$ & 0.099 & 0.041 & -0.039 & 0.124 \\
Non-metallic minerals & 0.131 & $0.152^{*}$ & 0.013 & 0.026 & -0.075 & 0.022 \\
Metallurgy \& basic metals & 0.023 & $0.305^{* * *}$ & $0.100 * *$ & 0.076 & 0.025 & -0.099 \\
Machinery \& equipment & 0.034 & $0.284 * * *$ & 0.059 & $0.089 * *$ & -0.034 & 0.015 \\
High-tech machinery & 0.090 & $0.205^{* * *}$ & 0.067 & 0.023 & 0.071 & -0.091 \\
Motor vehicles, trailers & -0.013 & $0.168^{*}$ & $0.298^{* * *}$ & -0.066 & $0.195 * *$ & -0.160 \\
Furniture/Manufacturing n.e.c. & -0.100 & $0.194 * *$ & $0.211 * *$ & 0.040 & -0.119 & -0.036 \\
Total number of treated & 844 & 844 & 789 & 784 & 570 & 310 \\
Total number of controls & 1,918 & 1,949 & 1,794 & 1,665 & 1,294 & 644 \\
\hline
\end{tabular}

The number of treated and controls decreases with $s . *-$ significant at $10 \%$; ** - significant at $5 \%$; *** significant at $1 \%$

Table 16 Differences in the TFP growth rates to the pre-export TFP levels between export entrants and matched non-exporters

\begin{tabular}{|c|c|c|c|c|c|}
\hline Industry & $\mathrm{t}$ & $\mathrm{t}+1$ & $\mathrm{t}+2$ & $\mathrm{t}+3$ & $\mathrm{t}+4$ \\
\hline Food \& beverages & $0.109 * * *$ & $0.230 * * *$ & $0.431 * * *$ & $0.330 * * *$ & $0.359 * * *$ \\
\hline Textile, leather, apparel & $0.291 * *$ & $0.507 * * *$ & $0.493 * * *$ & $0.984 * * *$ & $1.185^{* * *}$ \\
\hline Wood \& paper & $0.447 * * *$ & $0.562 * * *$ & $0.502 * * *$ & $0.431^{*}$ & $0.969 *$ \\
\hline Printing \& publishing & -0.033 & 0.111 & 0.386 & 0.449 & 2.053 \\
\hline Coke \& chemistry & $0.167 * *$ & 0.145 & $0.298 * *$ & 0.086 & $0.366^{* *}$ \\
\hline Rubber \& plastic & $0.330 * * *$ & $0.454 * * *$ & $0.517 * * *$ & 0.114 & $0.365 *$ \\
\hline Non-metallic minerals & $0.152 *$ & $0.149^{*}$ & $0.197 *$ & 0.109 & -0.084 \\
\hline Metallurgy \& basic metals & $0.305^{* * *}$ & $0.383 * * *$ & $0.516^{* * *}$ & $0.445^{* * *}$ & 0.176 \\
\hline Machinery \& equipment & $0.284 * * *$ & $0.308 * * *$ & $0.396 * * *$ & $0.282 * * *$ & $0.244 * *$ \\
\hline High-tech machinery & $0.205^{* * *}$ & $0.189 * *$ & $0.214 * *$ & $0.309 * *$ & 0.230 \\
\hline Motor vehicles, trailers & $0.168^{*}$ & $0.401 * * *$ & $0.373 * * *$ & $0.623 * * *$ & $0.444 *$ \\
\hline Furniture/Manufacturing n.e.c. & $0.194 * *$ & $0.371 * * *$ & $0.335 * * *$ & -0.060 & -0.278 \\
\hline Total number of treated & 844 & 789 & 784 & 570 & 310 \\
\hline Total number of controls & 1,949 & 1,794 & 1,665 & 1,294 & 644 \\
\hline
\end{tabular}

The number of treated and controls decreases with $s . *_{-}^{*}$ significant at $10 \%$; ** - significant at 5\%; *** significant at $1 \%$ 


\section{Appendix E: Industry Technological Intensity}

A number of empirical studies applied the OECD technological industry classification to assess the impact of FDI knowledge spillovers on firm's productivity, performance and innovation. The classification, first proposed by Hatzichronoglou (1997), is based both on direct $R \& D$ intensity, defined as direct $R \& D$ expenditures as a percentage of industrial production (gross output), and R\&D embodied in intermediate and investment goods. ${ }^{28}$ However, when applying the OECD technology classification to analyze the performance of firms one has to bear in mind the differences in economic structure between advanced and developing countries that might lead to different sets of industries being characterized as high technology ones. Following the insights of Hatzichronoglou (1997), we verify the R\&D intensity of the manufacturing sectors in my data by calculating the share of R\&D expenditure in final production. This exercise should provide a guideline to the technological intensity of Ukrainian manufacturing sectors.

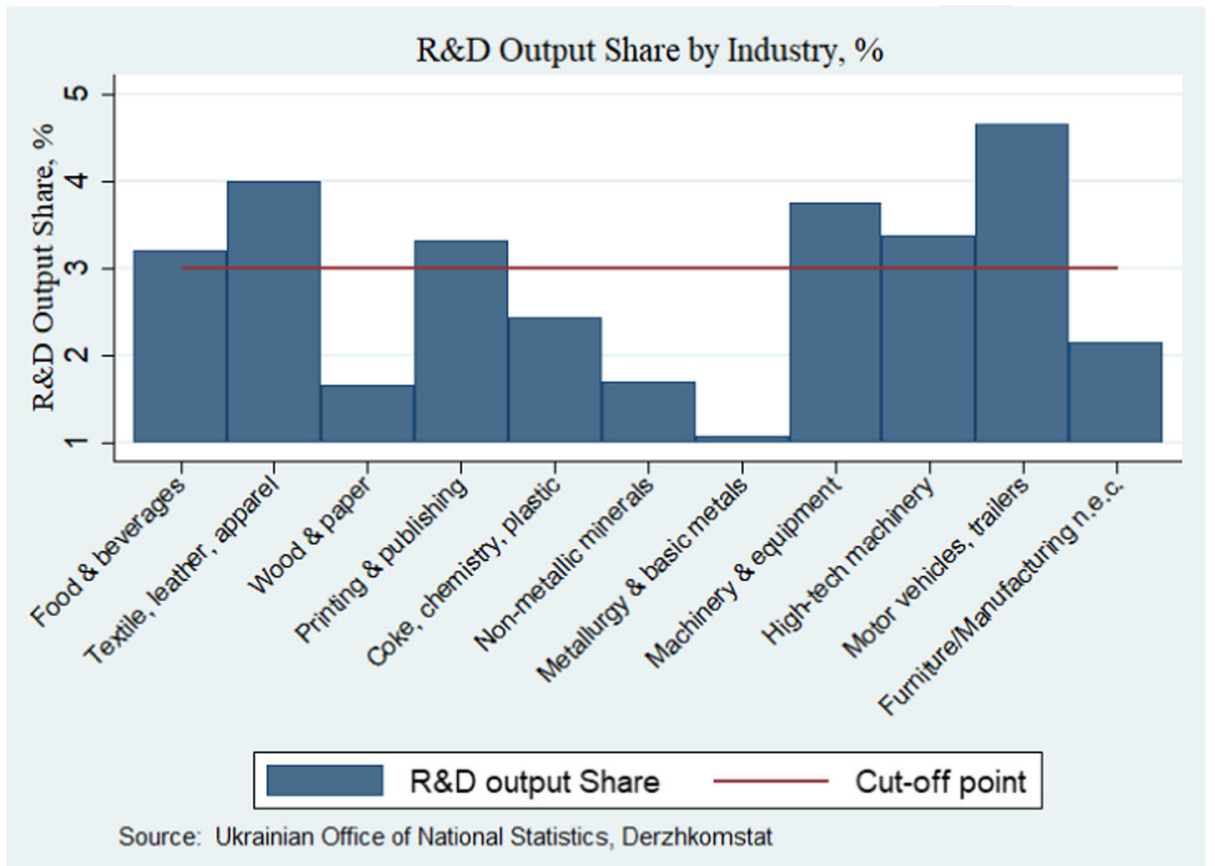

Fig. 5 R\&D output share by industry

The results show that in most cases Ukrainian manufacturing industries with higher R\&D output share correspond to the ones classified as high technology or medium-high

\footnotetext{
${ }^{28}$ The full list of NACE Rev.1 industries corresponding to the OECD technology classification can be found here: https://www.oecd.org/sti/ind/48350231.pdf.
} 
technology by the OECD (2011) report. The exceptions include food and beverages; textile leather and apparel; and printing and publishing industries. The OECD (2011) report includes these sectors in the low-technology category. However, according to the DIW (2012) report on assessing the innovation potential in Ukraine, food, beverages and tobacco, as well as printing and publishing, paper and wood industries exhibit relatively high shares of innovative production among Ukraine's key industrial sectors. The rest of the industries, including machinery and equipment, high technology machinery and motor vehicles and other transport equipment fall into the high technology category, in line with the OECD (2011) classification. Finally, the original OECD classification defines four technology categories as low-technology, medium-low-technology, medium-high-technology, and high-technology industries. For simplicity of the empirical analysis we distinguish between high technology and low technology industries only.

\section{References}

Andersson M, Loof H, Johansson S (2008) Productivity and international trade: firm level evidence from a small open economy. Rev World Econ/Weltwirtschaftliches Archiv 144(4):774-801

Aw BY, Chung S, Roberts MJ (2000) Productivity and turnover in the export market: micro-level evidence from the Republic of Korea and Taiwan (China). World Bank Econ Rev 14(1):65-90

Bernard AB, Jensen JB (1995) Exporters, jobs and wages in US manufacturing 1976-1987. Brookings Paper on Economic Activity. Microeconomics 1995:67-119

Bernard AB, Jensen JB (1999) Exceptional exporter performance: cause, effect or both? J Int Econ 47(1):125

Bernard AB, Wagner J (1997) Exports and success in german manufacturing. Rev World Econ 133(1):134 157

Bernard AB, Eaton J, Jensen JB, Kortum S (2003) Plants and productivity in international trade. Amer Econ Rev 93:1268-1290

Bernard AB, Jensen JB, Redding SJ, Schott PK (2007) Firms in international trade. J Econ Perspect 21(3):105-130

Blundell R, Costa Dias M (2000) Evaluation methods for non-experimental data. Fisc Stud 21(4):427-468

Castellani D, Serti F, Tomasi C (2010) Firms in international trade: importers' and exporters' heterogeneity in Italian manufacturing industry. World Econ 33(3):424-457

Clerides SK, Lach S, Tybout JR (1998) Is learning-by-exporting important? Micro-dynamic evidence for Colombia, Mexico, and Morocco. Q J Econ 113:903-48

Crino R, Epifani P (2012) Productivity, quality and export behaviour. Econ J 122:1206-1243

Damijan JP, Kostevc Č (2015) Learning from trade through innovation. Oxf Bullet Econ Stat 77(3):408-436

Damijan J, Polanec S, Prasnikar J (2004) Self-selection, export market heterogeneity and productivity improvements: firm level evidence from Slovenia LICOS Discussion Papers 14804. LICOS - Centre for Institutions and Economic Performance, KU Leuven

Dehejia R, Wahba S (1999) Causal effects in nonexperimental studies: Reevaluating the evaluation of training programs. J Amer Statist Assoc 94:1053-1062

Dehejia R, Wahba S (2002) Propensity score matching methods for nonexperimental causal studies. Rev Econ Stat 84:151-161

De Loecker J (2007) Do exports generate higher productivity? Evidence from Slovenia. J Int Econ 73(1):69_ 98

De Loecker J (2011) Product differentiation, multiproduct firms and trade liberalization on productivity. Econometrica 79(5):1407-51

De Loecker J (2013) Detecting learning by exporting. American Economic Journal: Microeconomics 5(3):121

DIW (2012) Assessing the innovation potential in Ukraine. Recent track record and implications for lowcarbon development, Technical Paper No. 1, German Institute for Economic Research, 2012

Eaton J, Kortum S, Kramarz F (2011) An anatomy of international trade: evidence from French firms. Econometrica 79(5):1453-98

Eliasson K, Hansson P, Lindvert M (2009) Do firms learn by exporting or learn to export? Evidence from small and medium-sized enterprises (SMEs) in Swedish manufacturing. Economic Studies Working Paper 15:1-34 
Girma S, Greenaway D, Kneller R (2004) Does exporting increase productivity? A microeconomic analysis of matched firms. Rev Int Econ 12(5):855-866

Greenaway D, Kneller R (2007) Firm heterogeneity, exporting and foreign direct investment. Econ J 117(517):134-161

Halvorsen R, Palmquist R (1980) The interpretation of dummy variables in semilogarithmic equations. Am Econ Rev 70(3):474-475

Harris R (2005) Economics of the workplace: special issue editorial. Scottish Journal of Political Economy 52(3):323-343

Harris R, Li C (2012) Export-market dynamics and firm-level productivity: evidence for UK tradable sectors. Ind Corp Chang 21(3):649-670

Hatzichronoglou T (1997) Revision of the high-technology sector and product classification. OECD science, technology and industry working papers, 1997/2, OECD Publishing

Heckman J, Ichimura H, Todd P (1997) Matching as an econometric evaluation estimator: evidence from evaluating a job training programme. Rev Econ Stud 64(4):605-654

Heckman J, Ichimura H, Todd P (1998) Matching as an econometric evaluation estimator. Rev Econ Stud 65(2):261-294

Huynh KP, Jacho-Chavez DT, Kryvtsov O, Shepotylo O, Vakhitov V (2016) The evolution of firm-level distributions for Ukrainian manufacturing firms. J Comp Econ 44(1):148-162

Isgut A (2001) What's different about exporters? Evidence from Colombian manufacturing. J Dev Stud 37(5):57-82

Isgut A, Fernandes A (2007) Learning-by-exporting effects: are they for real? MPRA Paper 3121. University Library of Munich, Germany

Klette T, Griliches Z (1996) The inconsistency of common scale estimators when output prices are unobserved and endogenous. J Appl Econ 114:343-361

Kostevc Č (2005) Performance of exporters: scale effects or continuous productivity improvements LICOS discussion papers 15905. LICOS - Centre for Institutions and Economic Performance, KU Leuven

Kostevc Č (2009) Foreign market competition as a determinant of exporter performance: evidence from Slovenian manufacturing firms. World Econ 32(6):888-913

Levinsohn J, Melitz M (2002) Productivity in a differentiated products market equilibrium, Harvard mimeo

Martins PS, Yang Y (2009) The impact of exporting on firm productivity: a meta-analysis of the learningby-exporting hypothesis. Rev World Econ 145(3):431-445

Melitz MJ (2003) The impact of trade on intra-industry reallocations and aggregate industry productivity. Econometrica 71(6):1695-1725

OECD Science, Technology and Industry Scoreboard 2011: Highlights, Organisation for Economic Cooperation and Development (2011)

Olley S, Pakes A (1996) The dynamics of productivity in the telecommunications equipment industry. Econometrica 64(6):1263-1298

Ornaghi C, Van Beveren I (2012) Semi-parametric estimation of production functions: a sensitivity analysis. Unpublished manuscript

Pavcnik N (2002) Trade liberalization, exit, and productivity improvement: evidence from Chilean plants. Rev Econ Stud 69(1):245-276

Pisu M (2008) Export destinations and learning-by-exporting: evidence from Belgium. National Bank of Belgium Working Paper, (140)

Rosenbaum P, Rubin D (1983) The central role of the propensity score in observational studies for causal effects. Biometrika 70:41-55

Shepotylo O, Vakhitov V (2015) Services liberalization and productivity of manufacturing firms. Evidence from Ukraine. Econ Transit 23(1):1-44

Silva A, Afonso O, Africano AP (2012a) Learning-by-exporting: what we know and what we would like to know. Int Trade J 26(3):255-288

Silva A, Afonso O, Africano AP (2012b) Which manufacturing firms learn by exporting? J Int Trade Econ Dev 21(6):773-805

Silva A, Afonso O, Africano AP (2013) Economic performance and international trade engagement: the case of Portuguese manufacturing firms. International Economics and Economic Policy 10(4):521-547

Smith J, Todd P (2005) Does matching overcome Lalonde's critique of nonexperimental estimators? J Econ 125:305-353

Van Biesebroeck J (2005) Exporting raises productivity in sub-Saharan African manufacturing firms. J Int Econ 67(2):373-391

Van Biesebroeck J (2007) Robustness of productivity estimates. J Ind Econ 55(3):529-569

Wagner J (2007) Exports and productivity: a survey of the evidence from firm-level data. World Econ 30(1):60-82 
Wagner J (2012) International trade and firm performance: a survey of empirical studies since 2006. Rev World Econ 148(2):235-267

Wakasugi R, Tanaka A (2009) Firm heterogeneity and different modes of internationalization: evidence from Japanese firms (KIER Working Paper 681). Kyoto University: Institute of Economic Research

Wilhelmsson F, Kozlov K (2007) Exports and productivity of Russian firms: in search of causality. Econ Chang Restruct 40(4):361-385

Yasar M, Raciborski R, Poi B (2008) Production function estimation in Stata using the Olley and Pakes method. Stata J 8(2):221-231

Yashiro N, Hirano D (2009) Do all exporters benefit from export boom?-evidence from Japan (KIER Working Paper 689). Kyoto University: Institute of Economic Research 